\title{
Keeping Dairy Cows for Longer: A Critical Literature Review on Dairy Cow Longevity in High Milk-Producing Countries
}

\author{
Gabriel M. Dallago ${ }^{1, *}\left(\mathbb{D}\right.$, Kevin M. Wade ${ }^{1}\left(\mathbb{D}\right.$, Roger I. Cue ${ }^{1}$, J T. McClure ${ }^{2}$, René Lacroix ${ }^{3}$, Doris Pellerin ${ }^{4}$ and \\ Elsa Vasseur ${ }^{1}$ \\ 1 Department of Animal Science, McGill University, Sainte-Anne-de-Bellevue, QC H9X 3V9, Canada; \\ kevin.wade@mcgill.ca (K.M.W.); roger.cue@mcgill.ca (R.I.C.); elsa.vasseur@mcgill.ca (E.V.) \\ 2 Department of Health Management, Atlantic Veterinary College, University of Prince Edward Island, \\ Charlottetown, PE C1A 4P3, Canada; jmcclure@upei.ca \\ 3 Lactanet, Valacta, 555 Boul des Anciens-Combattants, Sainte-Anne-de-Bellevue, QC H9X 3R4, Canada; \\ rlacroix@lactanet.ca \\ 4 Département des Sciences Animales, Université Laval, Québec, QC G1V 0A6, Canada; \\ doris.pellerin@fsaa.ulaval.ca \\ * Correspondence: gabriel.dallago@mail.mcgill.ca
}

Citation: Dallago, G.M.; Wade, K.M.; Cue, R.I.; McClure, J.T.; Lacroix, R.; Pellerin, D.; Vasseur, E. Keeping Dairy Cows for Longer: A Critical Literature Review on Dairy Cow Longevity in High Milk-Producing Countries. Animals 2021, 11, 808. https://doi.org/10.3390/ani11030808

Academic Editor: Clive J. C. Phillips

Received: 15 January 2021

Accepted: 9 March 2021

Published: 13 March 2021

Publisher's Note: MDPI stays neutral with regard to jurisdictional claims in published maps and institutional affiliations.

Copyright: (c) 2021 by the authors. Licensee MDPI, Basel, Switzerland. This article is an open access article distributed under the terms and conditions of the Creative Commons Attribution (CC BY) license (https:// creativecommons.org/licenses/by/ $4.0 /)$.
Simple Summary: The ability of farms to produce milk sustainably is closely related to dairy cow longevity, i.e., the length of productive life. However, longevity is a very complex feature that depends on all the aspects of the lifespan of a cow and there is no standard definition nor metric to measure it. Measuring longevity is important because it influences the profitability and the environmental impact of farms as well as the welfare of the animals. The objectives of this paper were to review metrics used to measure longevity and describe its status among high milk-producing countries. Increasing dairy cow longevity would imply that an animal has an early age at first calving and a long and profitable productive life. Combining age at first calving, length of productive life, and margin over all (available) costs provides a complete evaluation of longevity. This paper also shows that dairy cow longevity has decreased in most high milk-producing countries over time, which confirm the concerns voiced by the dairy industry and other stakeholders. Increasing cow longevity would reduce health costs and increase cow profitability while improving both animal welfare and quality of life, contributing to a more sustainable dairy industry.

Abstract: The ability of dairy farmers to keep their cows for longer could positively enhance the economic performance of the farms, reduce the environmental footprint of the milk industry, and overall help in justifying a sustainable use of animals for food production. However, there is little published on the current status of cow longevity and we hypothesized that a reason may be a lack of standardization and an over narrow focus of the longevity measure itself. The objectives of this critical literature review were: (1) to review metrics used to measure dairy cow longevity; (2) to describe the status of longevity in high milk-producing countries. Current metrics are limited to either the length of time the animal remains in the herd or if it is alive at a given time. To overcome such a limitation, dairy cow longevity should be defined as an animal having an early age at first calving and a long productive life spent in profitable milk production. Combining age at first calving, length of productive life, and margin over all costs would provide a more comprehensive evaluation of longevity by covering both early life conditions and the length of time the animal remains in the herd once it starts to contribute to the farm revenues, as well as the overall animal health and quality of life. This review confirms that dairy cow longevity has decreased in most high milk-producing countries over time and its relationship with milk yield is not straight forward. Increasing cow longevity by reducing involuntary culling would cut health costs, increase cow lifetime profitability, improve animal welfare, and could contribute towards a more sustainable dairy industry while optimizing dairy farmers' efficiency in the overall use of resources available. 
Keywords: animal welfare; cattle husbandry; cow longevity; productive lifespan; profitability; sustainability

\section{Introduction}

Dairy cow longevity is the length of life of the animal, which in turn is determined by either culling decision made by the producer or death of the animal. The removal of cows from dairy herds due to old age is rare in the modern dairy industry and the economic interest associated with farm animals, which require them to achieve expected production levels, to reproduce regularly, and stay healthy [1,2], influences the farmer's decision regarding the optimum moment to cull a cow. It is a complex decision process and a myriad of factors are to be considered by the dairy farmer [3]. Therefore, longevity is a compound feature reflecting a successful combination of many different aspects during the lifespan of a cow [4]. Dairy cow longevity is linked to the economic performance of farms, the environmental footprint of the milk industry, and the welfare status of the animals [1,5-9], and short cow longevity limits the achievement of a sustainable dairy industry.

The genetic potential for longevity has increased over the years [10-12] reflecting the inclusion of functional traits in the calculation of estimated breeding values [4]. Even though dairy cow have a life expectancy of around 20 years [13], this is rarely observed under modern commercial conditions. In Canada for example, the average age that Holstein cows die due to natural causes is 9.1 years [4]. This would represent a productive life (length of time between first calving and culling/death) of 6.8 years or about 6 lactations if an average age at first calving of 27 months is assumed [4]. This has been appointed as a problem by the dairy industry and, contrary to milk recording, there is no standardized approach to measure longevity which results in different metrics being used by different countries [14]. Increasing dairy cow longevity could be a strategy to improve the efficiency of using resources available to the dairy farmer and to produce milk with inherited sustainability.

The purpose of this critical literature review is to provide an integrated view of dairy cow longevity combined with the analysis of its status by focusing on phenotypical aspects of longevity rather than its genetic aspects. The objectives were to (1) review metrics commonly used to measure dairy cow longevity and, (2) use the most common metric to describe the status of longevity in high milk-producing countries. We hypothesized that limitations exist on current longevity metrics such as the lack of both a standard metric and reporting by dairy herd improvement (DHI) agencies or national databases. The significance of this critical review is to overcome these limitations by developing a standard methodology to estimate longevity metrics, which allow for a fair comparison between different countries, and by demonstrating that dairy cow longevity has decreased over the years in most high milk-producing countries. Addressing these two objectives will then lead us to answering the following questions: (i) should we improve dairy cow longevity? and (ii) how can we improve dairy cow longevity? and result in (iii) proposing a more comprehensive definition of cow longevity.

\section{How Can We Measure Longevity?}

The longevity of dairy cows is influenced by culling decisions made by the dairy farmer since culling ultimately defines the total length of time a cow remains in the herd. Therefore, common longevity metrics reflect culling strategies as well as the different stages of the life of a dairy cow.

\subsection{Culling}

Culling is the process of removing an animal from the herd due to death, salvage, sale, or slaughtering [2]. Apart from death, culling is a decision usually made by the dairy farmer and it is influenced by the economic interest associated with farm animals. Culling 
can be further classified as voluntary or involuntary based on the main reason underlying the culling decision. Voluntary culling occurs when a fertile and healthy animal is culled due to low milk production $[2,15]$. On the other hand, an involuntary culling happens if low milk production is not the culling reason $[2,15]$.

Involuntary culling accounts for most of the removal of dairy cows with known reasons. For example, in Canada, the average involuntary culling was 73.6\% (Standard deviation; SD = 0.65) between 2014 and 2019, while the averages of voluntary culling and culling with unknown reason were $7.18 \%(\mathrm{SD}=0.28)$ and $20.7 \%(\mathrm{SD}=2.3)$, respectively, in the same period [16]. The high percentage of culling with unknown reason indicates the existence of limitations among producers to keep track of culling records within the farm and reporting it. Reproduction $(16.8 \%$; $\mathrm{SD}=0.51)$, mastitis $(10.6 \%$; $\mathrm{SD}=0.66)$, and feet and leg problems $(6.88 \%$; $\mathrm{SD}=0.33)$ were the main reasons for involuntary culling during this period [16]. Similarly, infertility (20.4\%), udder health (14.7\%), and leg disorders (12.2\%) have been reported as the main reasons for involuntary culling in Germany between 2010 and 2013 [17]. The prevalence of the main culling reasons remained stable over time. In a meta-analysis conducted by Compton et al. [18] on 51 published papers regarding 54 studies conducted in 22 different countries between 1989 and 2014, the annual incidence risk of culling due to udder and reproduction issues did not change for almost two decades starting at the mid-1980s. At the same time, there was a decrease in culling due to low milk production (voluntary culling). A similar condition was observed in Canada (Figure 1), in which the percentage of involuntary culling remained stable between 1997 and 2019 [16] for reproduction, mastitis, and feet and leg problems, while the culling for low milk production decreased up to 2008 after which it was seen a slight upwards trend. The main reason for such reduction in the voluntary culling is likely due to the genetic selection for high milkyielding cows, which reduces the relative risk of being culled due to low milk production and is likely to continue as an objective of dairy farms [18].

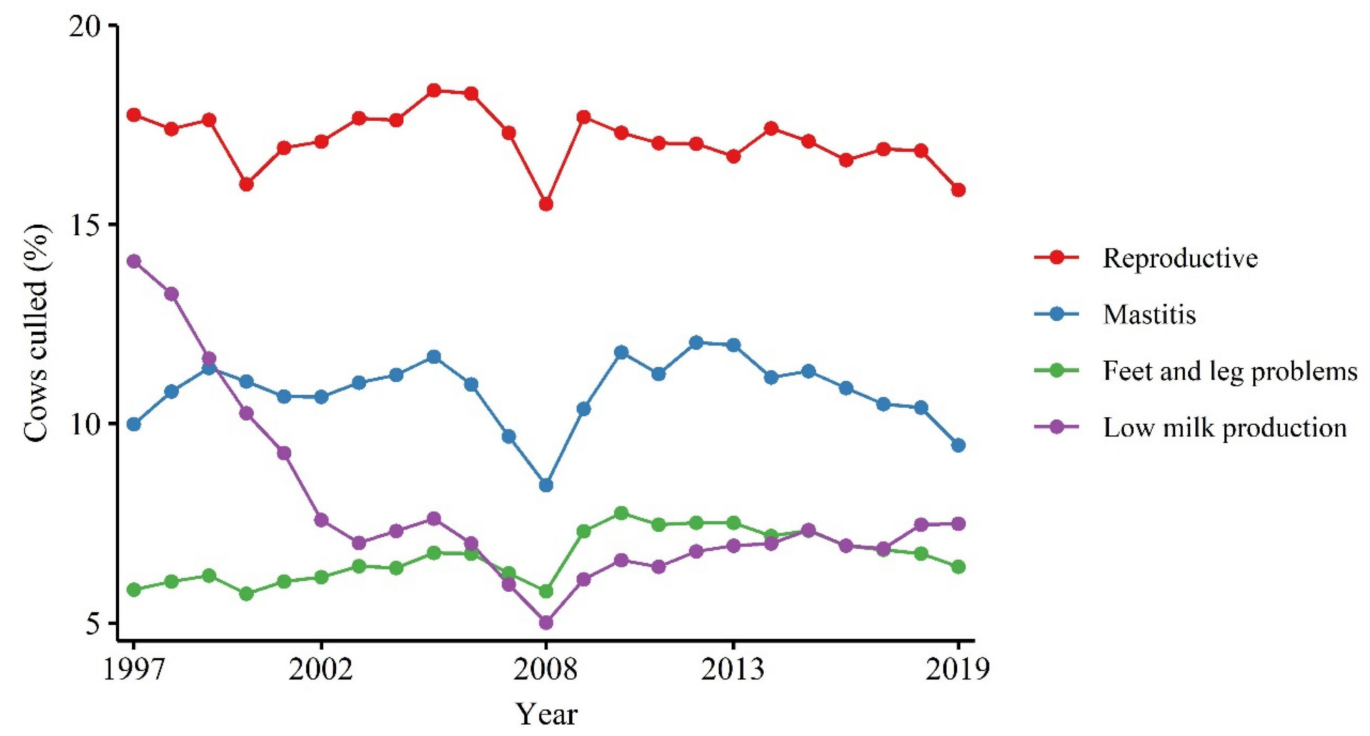

Figure 1. Change over time of the top four culling reasons based on the total number of cows culled with a known reported reason in Canada between 1997 and 2019 [16].

The risk of culling is not constant over the life of a cow. It depends on cow factors such as lactation number, stage of lactation, milk yield, and reproductive status as well as environmental factors such as season of calving and herd-production needs [17,19-22]. Death, as well as diseases and injury, are the main reasons for culling early after the onset of a new lactation $[19,20]$. On the other hand, the risk of culling due to failure to reproduce and low milk production increases as the lactation progress and the highest risk is observed at later stages of the lactation $[17,19,20]$. Milk yield and reproduction are protective factors 
against culling, in which pregnant [21] and high yielding animals are less likely to be culled compared with its counterpart $[19,23]$. Death is mostly associated with seasonal effects in which hot seasons are associated with a greater risk of dying [19]. Cows are favored to remain in the herd if they are healthy, reproduce regularly, have functional feet, legs, and udders, and produce enough milk $[1,2,13]$.

\subsection{Longevity Measures}

Longevity can be categorized as true, functional, and residual longevity. True longevity indicates the ability of an animal to delay culling, but it is not adjusted for milk yield [14]. Functional longevity indicates the ability of an animal to delay involuntary culling, and it is adjusted for milk yield within the herd [14]. Lastly, residual longevity represents cow longevity after adjusting it for all other traits under consideration in the breeding program [14]. Having culling or death as the endpoint and based on the different stages of the life of a dairy cow (Figure 2), different longevity metrics have been used (Table 1). These metrics can be obtained at the herd-level when they reflect the overall prevalence of animals that meet certain criteria such as the number of animals on third or greater lactation, or at the animal-level when each animal is individually evaluated.

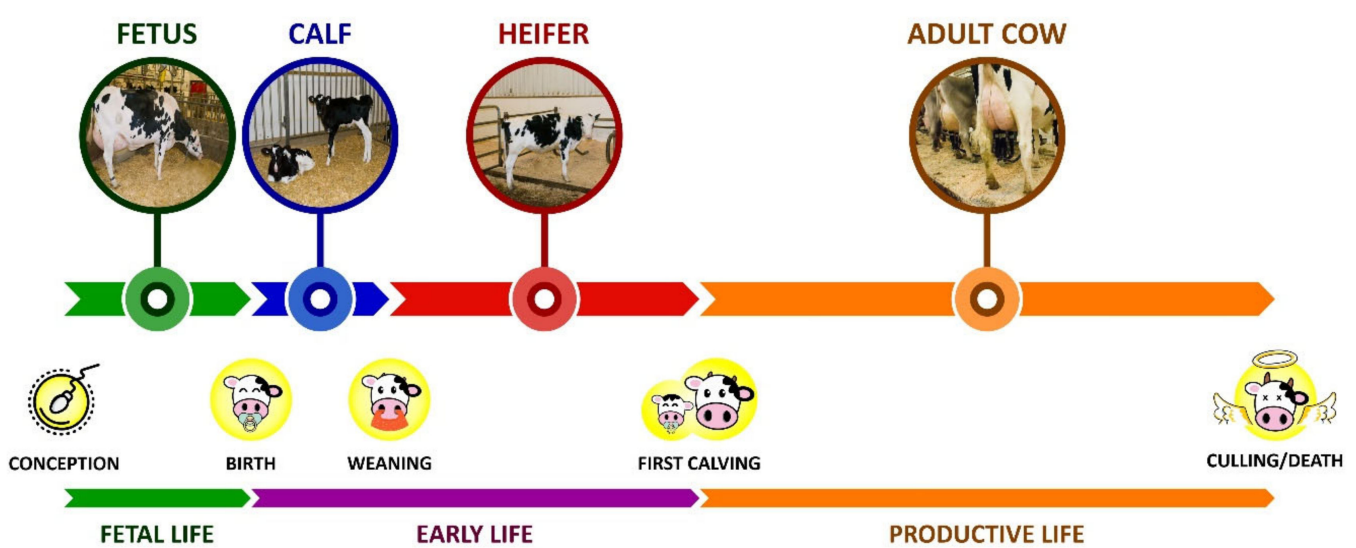

Figure 2. Schematic representation of the life of a dairy cow according to a chronological sequence of key events (conception, birth, weaning, first calving, and culling/death) that prompt a change to the different life status (fetus, calf, heifer, and adult cow) and respective life stages (fetal, early, and productive life). The length of the arrows is proportional to the duration of each status and stage as seen in the province of Quebec, Canada [24].

Table 1. Dairy cow longevity metrics commonly used.

\begin{tabular}{ccccc}
\hline Measure & Unit & Time Frame & Description & Reference \\
\hline Lactation & Count & $\begin{array}{c}\text { First calving to } \\
\text { culling/death }\end{array}$ & $\begin{array}{c}\text { Cumulative number of } \\
\text { lactations }\end{array}$ & Essl [1] \\
\hline 3+ lactation & $\begin{array}{c}\text { Herd } \\
\text { prevalence }\end{array}$ & $\begin{array}{c}\text { The number at a given } \\
\text { point }\end{array}$ & $\begin{array}{c}\text { Percentage of cows on } \\
\text { the third or greater } \\
\text { lactation }\end{array}$ & $\begin{array}{c}\text { Villettaz Robichaud et al. [25],Villettaz } \\
\text { Robichaud et al. [26],Villettaz Robichaud } \\
\text { et al. [27] }\end{array}$ \\
$\begin{array}{c}\text { Culling rate } \\
\text { prevalence }\end{array}$ & The number at a given \\
point & Percentage of culling & $\begin{array}{c}\text { Villettaz Robichaud, Rushen, de Passillé, } \\
\text { Vasseur, Haley, Orsel and Pellerin } \\
\text { [25],Villettaz Robichaud, Rushen, de } \\
\text { Passillé, Vasseur, Orsel and Pellerin } \\
\text { [26],Villettaz Robichaud, Rushen, de } \\
\text { Passillé, Vasseur, Haley and Pellerin [27] }\end{array}$ \\
\hline $\begin{array}{c}\text { Length of } \\
\text { life }\end{array}$ & Year & Birth to culling/death & $\begin{array}{c}\text { Length of time between } \\
\text { birth and culling }\end{array}$ & Haworth et al. [28] \\
\hline $\begin{array}{c}\text { Length of } \\
\text { productive } \\
\text { life }\end{array}$ & Year & $\begin{array}{c}\text { First calving to } \\
\text { culling/death }\end{array}$ & $\begin{array}{c}\text { Length of time between } \\
\text { first calving and culling }\end{array}$ & Ducrocq [29],Schneider et al. [30] \\
\hline
\end{tabular}


Table 1. Cont.

\begin{tabular}{ccccc}
\hline Measure & Unit & Time Frame & Description & Reference \\
\hline $\begin{array}{c}\text { Functional } \\
\text { longevity }\end{array}$ & Rank & $\begin{array}{c}\text { First calving to } \\
\text { culling/death }\end{array}$ & $\begin{array}{c}\text { Length of productive } \\
\text { life adjusted for } \\
\text { within-herd milk } \\
\text { production level }\end{array}$ & Sewalem et al. [31] \\
\hline $\begin{array}{c}\text { Longevity } \\
\text { index }\end{array}$ & $\%$ & Birth to culling/death & $\begin{array}{c}\text { Lifetime days in milk } \\
\text { divided by length of } \\
\text { life }\end{array}$ & $\begin{array}{c}\text { Brickell and Wathes [5], Haworth, Tranter, } \\
\text { Chuck, Cheng and Wathes [28] }\end{array}$ \\
\hline
\end{tabular}

The different longevity metrics can be classified as stayability metrics or lifetime metrics. Stayability metrics have a binary nature and indicate if a dairy cow is alive at a given moment in time [32] and can be updated as the animal grows. An example would be if the cows reach the third or greater lactation [25-27]. Even though such metrics do not provide a complete picture of cow longevity, one of their advantages is that they can be measured at any time [32]. On the other hand, lifetime metrics take into account the completed life stages of the animals [32]. For example, the life of a dairy cow can be split into early life (non-productive) and productive stages (Figure 2) from a production perspective. Based on that, longevity can be measured as the length of the productive life of a dairy cow $[29,30]$. Since lifetime metrics take into account the entire stage of life, they can only be calculated when such a stage is completed, which is one of the main limitations of such metrics.

Most lifetime metrics of dairy cow longevity do not specifically account for the early life stage (Figure 2), since they typically have first calving as the starting point. The longevity index (Table 1) is a proposed metric that overcomes such limitation by taking into account both the length of life of an animal and the length of time spent on producing milk [28]; therefore, accounting for the entire non-productive period of life (early life stage) and days dry of a dairy animal.

\subsection{Limitation of Common Longevity Measures}

There is no standard metric to measure dairy cow longevity and even though each different metric reflects an aspect of dairy cow longevity, they are not comparable since they do not have the same meaning [4]. Mark [14] estimated the correlation between longevity metrics used by different Interbull (an international network that carries on genetic analysis of livestock animals) member countries. The author reported a low correlation coefficient $(0.59)$ and high variability (range $=0.96$ ) among all countries evaluated, regardless of how longevity was measured/defined in each country. However, the correlation increased $(0.71)$ and the variability decreased (range $=0.51$ ) while analyzing only countries that used comparable longevity traits. Differences in how longevity was measured between countries could be partially the reason for low correlation and great variability in both cases, but a correlation lower than unity among countries that used comparable metrics could also be due to differences in culling reasons and trait definitions [14], which indicates a lack of standardization on measuring longevity. At the same time, the differences in the environment could be a reason for slight differences in traits among different countries as well.

\section{What Is the Current Status of Dairy Cow Longevity and Milk Yield?}

The average length of productive life, which is one of the most common longevity metrics, can be estimated based on the culling rate $[13,33,34]$. Since information at country level regarding culling is not available for most countries, a proxy can be estimated based on slaughtering data at country level, even though this approach would not take into account animals that died in the farm and would assume the accuracy of slaughter records reported by each country. Once this information is obtained, it can be used to evaluate the trend over time in the status of dairy cow longevity along with milk yield per animal. The 
following methodology was used to identify high milk-producing countries and estimate dairy cow longevity at the country level.

\subsection{Sourcing the Information}

Countries were first ranked based on total milk production to identify the ones with the highest production. As a starting point, the average total whole fresh cow milk was calculated based on 2016, 2017, and 2018 information provided by the FAO [35]. The top 21st high milk-producing countries were kept. Next, we searched for yearly official statistics publications for each of these countries regarding the total number of dairy cows, total milk production $(\mathrm{kg})$, average milk yield per animal $(\mathrm{kg})$, and the number of slaughtered cows. No date limit was imposed at this stage and all information available was gathered and aggregated into a single data file. For countries that reported milk production in liters it was converted to $\mathrm{kg}$ using the 1.03 conversion factor. For countries that did not officially report average milk yield, it was estimated by dividing the reported total milk production over the number of dairy cows (Table A1). References and official sources are presented in Table A1.

The length of productive life was estimated based on the culling rate. A proxy of the average culling rate was estimated at the country level by dividing the number of dairy cows slaughtered per year by the total number of dairy cows in each year for the countries that we were able to find both information. For countries that did not specify the number of dairy cows slaughtered, we used the number of cows slaughtered (Table A1). The inverse of the culling rate was then used as an estimation of the length of productive life $[13,33,34]$.

Once the data was gathered and calculations were completed, two criteria were used in data cleaning to define its sufficiency and reliability, respectively. First, only countries that we were able to find information for at least two consecutive decades were kept for further steps. Next, information from countries in which cows had a length of productive life lower than 1.5 years (Argentina, Australia, and Mexico) in earlier decades or greater than 7 years (Turkey and United Kingdom) in recent decades were considered unreliable and excluded from further steps in this review. After cleaning, information from 10 countries remained (Figure 3; Table A1).

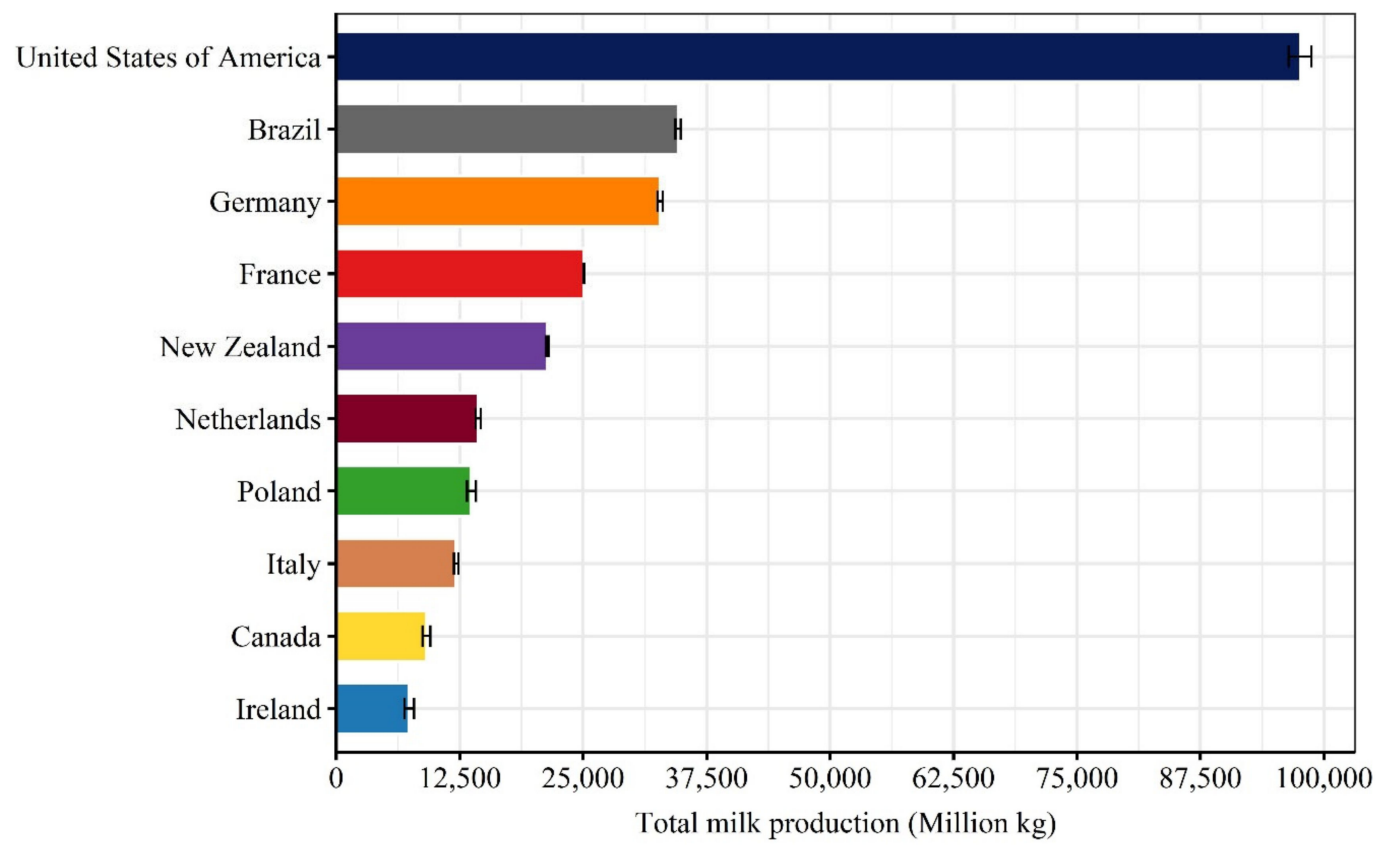

Figure 3. Top 10 high milk-producing countries based on total milk production averaged over the years 2016 to 2018. Columns represent the averages followed by the standard deviation (error bars). The list of countries is limited to those for which we were able to provide sufficient and reliable data on the length of productive life. Data sources are provided in Table A1. 
Linear regression was used to describe the trend over time in both milk yield and length of productive life. For milk yield, we reduced the number of observations to standardize the time window interval for all countries. Therefore, we considered only the information ranging from 1961 to 2018, which represented $96.9 \%$ of the data available after cleaning. For the length of productive life, it was not possible to establish a standard time window. For some countries, we were able to find reliable information only from more recent years while for others the collection was more extensive. The following polynomial regression model was used to describe both trends:

$$
Y_{j}=\beta_{0}+\beta_{1} \text { Year }_{j}+\varepsilon_{j},
$$

in which $Y_{j}$ represented the milk yield per animal $(\mathrm{kg})$ or length of productive life (year), $\beta_{0}$ was the intercept, $\beta_{1}$ was the linear regression coefficient, Year $_{j}$ was the value observed in the jth year and $\varepsilon_{j}$ was the residual error $\sim N\left(0, \sigma^{2}\right)$. Statistical significance level was set at $\alpha<0.05$.

\subsection{Milk Yield and Longevity Over Time}

The average milk yield per animal per year increased in all the countries considered in this review (Figure 4). However, the magnitude of the increase was not the same across countries. The estimated increase ranged from $18.5 \mathrm{~kg}$ (Standard error; $\mathrm{SE}=1.49$ ) per animal per year in Brazil to $129.7 \mathrm{~kg}$ (SE = 1.20) $\mathrm{kg}$ in the United States both from 1961 to 2018 (Table 2).

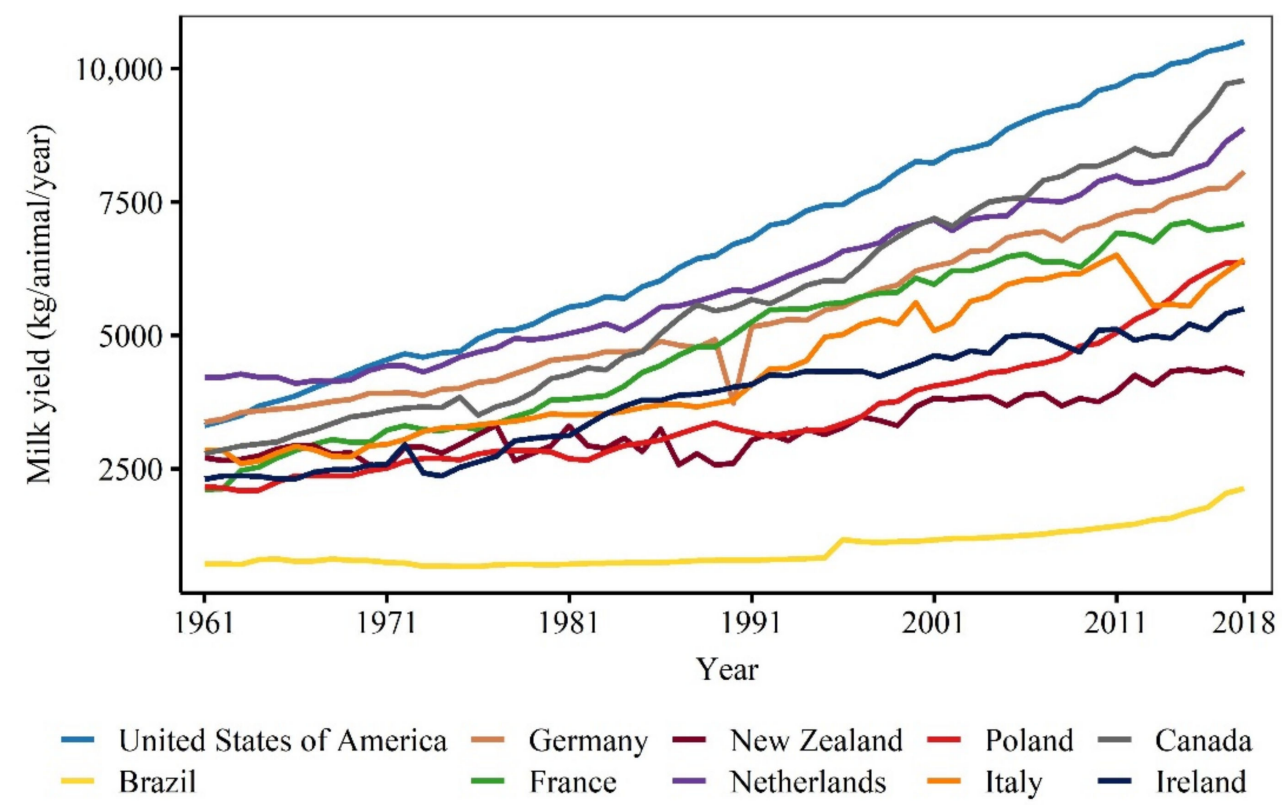

Figure 4. The average milk yield $(\mathrm{kg})$ per animal from the top 10 high milk-producing countries over the years. The list of countries is limited to the world's top high milk-producing countries for which we were able to provide sufficient and reliable data on the length of productive life. Data sources are provided in Table A1. 
Table 2. The linear trend of milk yield (kg) per animal per year for each country between 1961 and 2018. The list of countries is limited to the world's top high milk-producing countries for which we were able to provide sufficient and reliable data on the length of productive life.

\begin{tabular}{|c|c|c|c|c|c|}
\hline \multirow{2}{*}{ Country } & \multicolumn{2}{|c|}{ Model $^{1}$} & \multirow{2}{*}{$R^{23}$} & \multirow{2}{*}{ RSE $^{4}$} & \multirow{2}{*}{$p$-Value ${ }^{5}$} \\
\hline & Intercept $^{2}$ & Year $^{2}$ & & & \\
\hline $\begin{array}{c}\text { United States of } \\
\text { America }\end{array}$ & $\begin{array}{c}2941.6^{* * *} \\
(40.6)\end{array}$ & $\begin{array}{c}129.7 * * * \\
(1.20)\end{array}$ & 0.99 & 152.5 & $<0.001$ \\
\hline Brazil & $\begin{array}{l}451.2 * * * \\
(50.4)\end{array}$ & $\begin{array}{l}18.5^{* * *} \\
(1.49)\end{array}$ & 0.73 & 189.5 & $<0.001$ \\
\hline Germany & $\begin{array}{c}2904.6^{* * *} \\
(83.4)\end{array}$ & $\begin{array}{l}81.4^{* * *} \\
(2.46)\end{array}$ & 0.95 & 313.4 & $<0.001$ \\
\hline France & $\begin{array}{l}2103.8^{* * *} \\
(56.8)\end{array}$ & $\begin{array}{l}91.9 * * * \\
(1.68)\end{array}$ & 0.98 & 213.6 & $<0.001$ \\
\hline New Zealand & $\begin{array}{c}2419.1^{* * *} \\
(70.9)\end{array}$ & $\begin{array}{c}29.0 * * * \\
(2.09)\end{array}$ & 0.77 & 266.7 & $<0.001$ \\
\hline The Netherlands & $\begin{array}{c}3485.8^{* * *} \\
(61.2)\end{array}$ & $\begin{array}{c}84.3^{* * *} \\
(1.80)\end{array}$ & 0.97 & 230.0 & $<0.001$ \\
\hline Poland & $\begin{array}{c}1603.6^{* * *} \\
(107.4)\end{array}$ & $\begin{array}{c}65.3^{* * *} \\
(3.17)\end{array}$ & 0.88 & 403.8 & $<0.001$ \\
\hline Italy & $\begin{array}{c}2200.5^{* * *} \\
(91.3)\end{array}$ & $\begin{array}{l}72.5^{* * *} \\
(2.69)\end{array}$ & 0.93 & 343.1 & $<0.001$ \\
\hline Canada & $\begin{array}{c}2081.3^{* * *} \\
(84.1)\end{array}$ & $\begin{array}{c}120.7^{* * * *} \\
(2.48)\end{array}$ & 0.98 & 316.3 & $<0.001$ \\
\hline Ireland & $\begin{array}{c}2035.0^{* * *} \\
(53.3)\end{array}$ & $\begin{array}{l}59.9 * * * \\
(1.57)\end{array}$ & 0.96 & 200.5 & $<0.001$ \\
\hline
\end{tabular}

Improvements in nutrition, genetics, animal health, and management of environmental factors contributed to the increase in milk yield [36,37]. However, the relative weight of such factors is likely not the same across countries. For instance, the tropical climate in Brazil limits the raising of high yielding animals such as Holstein cows, which are particularly susceptible to heat stress [38] and had their susceptibility highlighted due to intensive selection for milk production [36]. Climatic conditions are not as limiting in countries under a similar low input pasture-based production system than Brazil but located in a cooler climate zone, such as New Zealand, where climatic conditions are adverse towards production for only up to $20 \%$ of days in a year [39]. On the other hand, milk yield increase in typical indoor-housing high input systems such as in the Netherlands, United States, and Canada was achieved by intense selection of animals based on milk production instead of increasing their resistance to climatic stressors and focused on improving nutritional management and developing artificial thermal conditioning systems [36].

Three different status of dairy cow longevity were observed in top high milk-producing countries (Figure 5). In most countries (6 out of 10), the length of productive life significantly decreased over the years, with a total estimated decrease ranging from 0.90 year in Ireland to 3.04 year in Poland (Table 3). New Zealand was the only country in which the length of productive life increased over time, with a total estimated increase of 1.85 years (Table 3). The length of productive life did not change in the United States, Germany, and the Netherlands (Table 3) with an average of 3.25 (SE = 0.09), $3.24(\mathrm{SE}=0.07)$, and 3.14 $(\mathrm{SE}=0.17)$ years, respectively.

In order to look at the relationship between milk yield and longevity, the differences in production systems need to be considered since not every country uses the same system. For instance, most herds in New Zealand are under a low input pasture-based system while in Canada and the Netherlands cows are typically housed indoors. The average 
milk yield per animal in New Zealand in 2018 was 2.3 and 2.1 times lower than in Canada and the Netherlands, respectively (Figure 4), which was expected since milk yield in a pasture-based system is usually lower compared to indoor-housed systems. The opposite was observed for longevity between these countries. In the 2010s decade, the average length of productive life in New Zealand was 2.5 and 1.5 times higher compared to Canada and the Netherlands, respectively (Figure 5).

The highest incidence of involuntary culling due to fertility issues and health problems such as mastitis and lameness is one of the main factors responsible for a reduction in dairy cow longevity [40]. Involuntary culling reduces the ability of dairy farmers to select animals based on production once they reach the productive life stage [41,42], forcing farmers to cull an animal that would otherwise be kept in the herd. However, such high incidence is not a reality in all farms within countries, indicating differences among farmers in their ability to keep animals healthy and comfortable for longer in the herd based on adopting management and housing practices that in turn prevent the occurrence of health problems associated with involuntary culling [40].

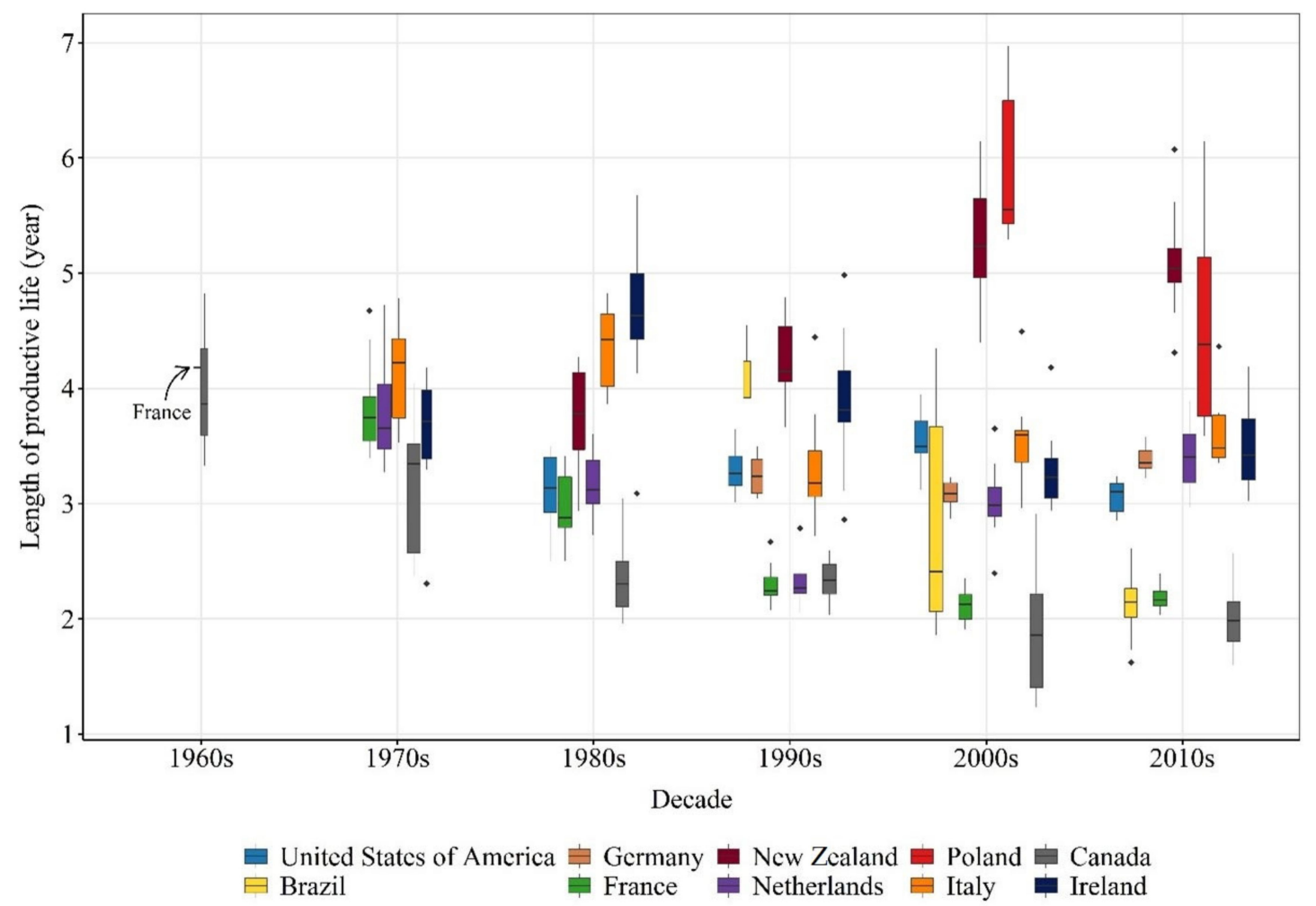

Figure 5. The length of productive life (year) of dairy cows from the top 10 high milk-producing countries on different decades. The relative width of each box per country within decades represents the number of observations available to generate it. The wider the box, the more observations were available. The list of countries is limited to the world's top high milk-producing countries for which we were able to provide sufficient and reliable data on the length of productive life. Full circles $(\bullet)$ represent values above or bellow the interquartile range. Data sources are provided in Table A1. 
Table 3. The linear trend of the length of productive life (year) in each country. The list of countries is limited to the world's top high milk-producing countries for which we were able to provide sufficient and reliable data on the length of productive life.

\begin{tabular}{|c|c|c|c|c|c|c|}
\hline \multirow{2}{*}{ Country } & \multirow{2}{*}{ Year } & \multicolumn{2}{|c|}{ Model $^{1}$} & \multirow{2}{*}{$R^{23}$} & \multirow{2}{*}{$\mathrm{RSE}^{4}$} & \multirow{2}{*}{$p$-Value ${ }^{5}$} \\
\hline & & Intercept $^{2}$ & Year $^{2}$ & & & \\
\hline $\begin{array}{c}\text { United States of } \\
\text { America }\end{array}$ & 1980-2019 & $\begin{array}{l}3.25^{* * *} \\
(0.10)\end{array}$ & $\begin{array}{c}0.0004^{\mathrm{NS}} \\
(0.004)\end{array}$ & 0.0003 & 0.30 & 0.92 \\
\hline Brazil & 1997-2018 & $\begin{array}{c}4.06^{* * *} \\
(0.24)\end{array}$ & $\begin{array}{c}-0.12 * * * \\
(0.02)\end{array}$ & 0.67 & 0.55 & $<0.001$ \\
\hline Germany & 1993-2019 & $\begin{array}{l}3.11^{* * *} \\
(0.07)\end{array}$ & $\begin{array}{l}0.01 \mathrm{NS} \\
(0.004)\end{array}$ & 0.13 & 0.18 & 0.06 \\
\hline France & 1968-2019 & $\begin{array}{l}3.89 * * * \\
(0.10)\end{array}$ & $\begin{array}{l}-0.04^{* * *} \\
(0.003)\end{array}$ & 0.76 & 0.37 & $<0.001$ \\
\hline New Zealand & 1982-2019 & $\begin{array}{l}3.69 * * * \\
(0.19)\end{array}$ & $\begin{array}{c}0.05^{* * *} \\
(0.01)\end{array}$ & 0.48 & 0.56 & $<0.001$ \\
\hline The Netherlands & 1970-2019 & $\begin{array}{c}3.38 * * * \\
(0.17)\end{array}$ & $\begin{array}{c}-0.01 \mathrm{NS} \\
(0.01)\end{array}$ & 0.05 & 0.59 & 0.12 \\
\hline Poland & 2003-2019 & $\begin{array}{l}6.81^{* * *} \\
(0.25)\end{array}$ & $\begin{array}{l}-0.19^{* * *} \\
(0.02)\end{array}$ & 0.79 & 0.50 & $<0.001$ \\
\hline Italy & 1970-2019 & $\begin{array}{l}4.26^{* * *} \\
(0.14)\end{array}$ & $\begin{array}{l}-0.02 * * * \\
(0.005)\end{array}$ & 0.22 & 0.49 & $<0.001$ \\
\hline Canada & 1967-2019 & $\begin{array}{l}3.38 * * * \\
(0.13)\end{array}$ & $\begin{array}{c}-0.03^{* * *} \\
(0.004)\end{array}$ & 0.57 & 0.47 & $<0.001$ \\
\hline Ireland & 1974-2019 & $\begin{array}{c}4.28^{* * *} \\
(0.21)\end{array}$ & $\begin{array}{c}-0.02 * \\
(0.01)\end{array}$ & 0.14 & 0.70 & 0.01 \\
\hline
\end{tabular}

$\overline{{ }^{1} \mathrm{NS}}=$ Not significant, ${ }^{*}=p$-value $<0.10,{ }^{* * *}=p$-value $<0.01 ;{ }^{2}$ Estimate (Standard error) ${ }^{3} \mathrm{R}^{2}=$ Coefficient of determination; ${ }^{4}$ RSE $=$ Residual standard error; ${ }^{5}$ Model significance.

Differences in production systems could be associated with the longevity status of the animals in different countries. Indoor housing and high input milk production system are two of the main characteristics shared by most of the high milk-producing countries in this review in which the length of productive life decreased over time. In turn, these are also two of the main differences compared to the production system in New Zealand, where the length of productive life increased. Even though a comparison between systems regarding their effect on the main involuntary culling reasons (reproduction, mastitis, and feet and leg problems) would be inevitably confounded by milk production and animal characteristics between countries even within the same breed, it could be a starting point in exploring the reasons underlying such differences in longevity between countries.

\subsection{Longevity and Involuntary Culling}

Information on culling and culling reasons is not available at the country level for most of the high milk-producing countries covered in this review. Therefore, we rely on herd prevalence reported by epidemiological studies, which are usually conducted on a limited number of animals and farms.

\subsubsection{Reproduction}

Failure to reproduce is the most frequent reason for involuntary culling worldwide $[16,17,19]$ and the incidence of uterine diseases have a negative effect on animal reproduction, which could lead to a shortened longevity. Endometritis is the most prevalent uterine disease in dairy cows. Its prevalence was 27.1 or $25.1 \%$, depending on the diagnostic method (degree of purulent vaginal discharge or cytology of the endometrium, respectively) in New Zealand [43]. In the United States, the prevalence of clinical en- 
dometritis was $15.0 \%$ [44] while the prevalence of subclinical endometritis ranged from $13.4 \%$ [44] to 53\% [45]. Uterine diseases have a negative effect on animal reproduction by increasing the number of artificial inseminations per pregnancy, delaying the restart of estrous cyclicity [44], and reducing the overall pregnancy rate [45-47]. Therefore, cows with high longevity are likely to have a better reproductive performance, such as shorter calving interval, require a lower number of inseminations to become pregnant, and reduced number of days to first service [42]. However, having had uterine diseases do not put the cow at a greater risk of being culled if she gets pregnant [46], which demonstrate the protective effect of a positive reproduction status (being pregnant) against involuntary culling.

The reproductive performance of cows under different production systems has not been extensively studied. The reproductive health (calving difficulty, puerperal metritis, and endometritis) of seasonally bred dairy cows in a rotational grazing system tended to be better compared to cubicle housed cows in Ireland [48]. A multi-year experimental study conducted by Washburn et al. [49] at the North Carolina State University-the United States between 1995 and 1998 compared the reproductive performance of seasonally bred Jersey and Holstein cows kept under pasture or housed in a free-stall barn. Reproductive performance was measured as the percentage of pregnant animals in 75 days after the beginning of the breeding season and no difference was observed $(p>0.05)$ between systems or between breeds. However, such results need to be interpreted carefully, especially in places with climatic conditions different from those observed in these studies since animals on pasture are more susceptible to the climatic environment, which in turn can negatively affect reproduction. During summer months, the conception rate of Holstein cows kept in paddocks with little or no shade decreased by $18 \%$ in a study conducted in Florida, US [50]. In addition, oocyte quality and the development of fertilized oocytes are negatively affected by the increase in temperature observed during the summer in Holsteins cows under pasture in Louisiana, US [51]. Such negative effects are likely to be intensified in the future, given the expected changes in climate conditions.

\subsubsection{Mastitis}

Mastitis is the most common disease in dairy cows and its occurrence varies between countries as well as within countries. The average incidence rate of clinical mastitis in Canada between November 2003 and July 2005 was $23.0 \%$, but it ranged from 0.7 to $97.4 \%$ [52], which indicates great variability between farms. In the Netherlands, the incidence of clinical mastitis was $33.8 \%(95 \% \mathrm{CI}=31.7-36.1)$ [53]. A much lower average incidence rate of $12.7 \%$ as well as a narrowed range from 1.9 to $35.8 \%$ was observed in New Zealand between July 2004 and June 2005 [54]. In Brazil, where most of the dairy animals are on a pasture-based system similar to New Zealand, the average prevalence of clinical mastitis was $46.4 \%$, but it ranged from 1.45 to $100 \%$ [55] while in Northern Ireland, where pasture is also largely used, the incidence was $29 \%$ between 2010 and 2015 [56].

Pasture-based systems are often associated with a lower occurrence of mastitis compared to indoor-housed cows. For instance, Jersey and Holstein cows housed in a free-stall barn had 1.8 times more cases of clinical mastitis compared to cows on pasture $(p<0.05)$, which resulted in free-stall cows having a culling rate due to mastitis eight times higher than cows on pasture in the United States [49]. Regular access to pasture was reported to be a protective factor against mastitis since it decreased the odds ratio of veterinary treated mastitis (Odds ratio; $\mathrm{OR}=0.73, p<0.05$ ) in Austria [57]. Indoor housing was also associated with a 4.86 OR of developing subclinical mastitis during the first 41 days of lactation in Germany [58].

The cleanliness of the animals, which indicates the level of exposure to environmental pathogens, seems to be one of the reasons for such a protective factor of pasture. The cleanliness of stalls in a free-stall barn was positively correlated with the hygiene scores for udder [59], which in turn was associated with increased somatic cell count [60,61]. Cows that had access to pasture were $3.75(\mathrm{SE}=1.89 ; p<0.05)$ times less likely to be dirty compared to cows that did not in Danish dairy farms [62]. However, the cleanliness of cows 
on pasture or at outdoor paddocks is directly influenced by climatic conditions, which in the rainy season is associated with dirtier cows while the opposite is observed during the dry season [63]. In addition, the occurrence of mastitis is associated with hygiene practices and improving those are a low-cost solution that improves animal performance [64] and the incidence of mastitis. In indoor housing, increasing the frequency of cleaning the barns could be a strategy to reduce the level of exposure to pathogens, since that cleaning the floors more than 4 times per day was associated with a reduction in clinical mastitis incidence $(\mathrm{OR}=0.77 ; 95 \% \mathrm{CI}=0.62-0.96 ; p<0.05)$ in the Netherlands [65].

\subsubsection{Feet and Leg}

The occurrence of lameness is lower in cows on pasture compared to indoor-housed cows. The prevalence in New Zealand is $8.1 \%$ [66] compared to $22.2 \%$ and $24.6 \%$ in Canada [67] and the United States [68], respectively. Such difference between systems is even present within the same countries. In the UK, Haskell et al. [69] reported that zero-grazing farms had 2.6 more lame cows compared to grazing farms while in the United States, Adams et al. [70] reported that in farms where cows were primarily housed in free-stall barns had an 6.9 (SE = 0.60) greater incidence density ratio of severely lame cows than in farms where cows were kept mainly in pasture. Concrete floor is a risk factor in increasing the incidence of claw lesions [71] and lameness [71,72]. To that end, access to pasture could be beneficial because it has been associated with improving hoof health, healing of lesions, and decreasing the incidence of lameness $[71,73,74]$. The low incidence of lameness in New Zealand could result in a reduction of involuntary culling due to feet and leg problems and potentially increase the longevity of dairy cows in this country compared to Canada and United States where pasturing cows is seldom practiced. However, in addition to information on culling not being available at the country level for most countries, failure in detecting lameness by farmers is a limiting factor in using herd prevalence as a proxy for culling reason. The prevalence of lameness is 3 to 4 times higher than that estimated by farmers $[66,68,75]$. In addition, lame cows are not necessarily culled since they can be treated if the producer chooses to do so. Lameness is also associated with negative reproductive performance and milk production [76], which in turn might be the reason reported for culling by the farmer.

By itself, the pasture-based system is not responsible for reducing the prevalence of lameness in dairy cows. An overall prevalence of 39\% was reported by Thompson et al. [77] while evaluating 252 dairy cows from six pasture-based herds in the southern region of Brazil, which is higher than that reported in indoor housed animals in Canada (22\%) [67] and US (24.6\%) [68]. Environmental conditions and management practices such as the amount of rainfall, condition of tracks to pasture, poor hygiene, and human-animal relationship are important factors associated with lameness in pasture-based farms $[78,79]$. In addition, most of the time, farmers can only report one reason for culling, and feet and leg issues may not be the primary reason for culling due to their failure to detect lame animals $[66,68,75]$.

\section{Should We Improve Dairy Cow Longevity?}

Short longevity poses a threat to the sustainability of the dairy industry since it is associated with financial losses on farms, increased environmental footprint of milk production, and welfare issues for the animals, which in turn is a growing social concern among consumers [1,5-9]. Therefore, improving dairy cow longevity would contribute to achieving a more sustainable industry, since it would have a positive effect towards the three pillars of sustainable agriculture: economic profit, environmental impact, and social concerns.

\subsection{Economic Profit}

For a dairy farm to be profitable, dairy cows need to be able to reproduce regularly, maintain high milk production, and do not fall ill for many years [80]. Therefore, increasing 
the length of productive life is a potential option to improve the profitability of the dairy activity [7]. In fact, it is the second most economically important trait in dairy cows, while milk yield is the first most important trait [81]. Short longevity indicates that animals are not expressing their maximum potential for productivity and profitability, since dairy cows become profitable at their third lactation due to high costs associated with the early life non-productive stage [8,9]. In addition, more first and second lactation cows are culled as culling rate increases [82], which decreases animal longevity and reduces the profitability of the system. Overall, the most common reason for culling of first and second lactation cows is reproduction issues while death is the most common reason for third and greater lactation cows [19]. During the initial third of the lactation, first calving cows are more likely to be culled due to low milk production and milkability while second lactation animals are culled due to the incidence of metabolic and other diseases [17]. However, higher risk of culling due to failure to reproduce is observed in the final third of the lactation for both first and second lactation cows [17]. With increasing longevity by decreasing the culling of animals in the beginning of their productive life, there will be a high number of cows on more profitable lactations in the herd and the replacement cost per day will be relatively reduced since it would be split into more lactations [1].

Having a greater proportion of mature cows because of increased longevity would reduce the number of replacement heifers required to achieve the same milk production since mature cows have a relatively higher milk yield compared to young animals. This is particularly relevant under a supply management system such as the one present in Canada [4], where profitability is associated with increased efficiency of using the resources available and reducing input costs rather than increasing milk production. However, it would allow for the commercialization of extra heifers $[5,10,42]$ and potentially increasing this additional source of income. In addition, increasing longevity by reducing involuntary culling would improve lifetime profit [1] especially given the negative economic impact of factors underlying health problems associated with involuntary culling [64].

Even though longer longevity alone does not assure an increase in profitability, a farm with short longevity due to a high involuntary culling and its associated diseases is not likely to be profitable either [34]. The adoption of management practices and technologies to improve cow health and longevity is essential to achieve a profitable dairy industry in the future, which is a key factor in achieving sustainability [83,84].

\subsection{Environmental Impact}

Increasing longevity would reduce the environmental toll of the dairy industry. Longer longevity would reduce the required number the replacement heifers needed on a farm, which contribute with 21 to $26 \%$ of the total enteric emission of methane in a herd [85]. At the same time, it would reduce the proportional emission from replacement heifers. Assuming an age at first calving of 28 months, Knapp et al. [86] estimated that increasing the length of productive life from 2.5 years ( $40 \%$ culling rate) to 4.0 years ( $25 \%$ culling rate) would reduce by $9.5 \%$ the enteric emission contribution of replacement heifers. In addition, methane emission per animal does not increase as the animal gets older [87]. In fact, an increase in the length of productive life was associated with a decrease in methane emission per $\mathrm{kg}$ of milk corrected for fat and protein [7], which contributes to decreasing the footprint associated with milk production [6] and supports the argument that increasing dairy cow longevity would decrease the environmental burden of the dairy industry.

\subsection{Social Concerns}

Early age at culling is a growing concern among consumers [88], especially because cow longevity is a global indicator of animal welfare since higher cow longevity indicates that the animal biological functions and health are not impairing the length of its life [89]. In addition, the health issues associated with the most common reasons for involuntary culling reported by dairy farmers bring into question the welfare conditions and ethical concerns towards dairy farming [34]. 
The high incidence of involuntary culling due to reproduction problems $[16,17,19]$ might hide underlying health problems. For instance, the occurrence of reproductive diseases [44-47] as well as lameness [76] and mastitis [90] have a negative effect on the ability of an animal to get pregnant and might result in animals being culled with failure to reproduce as the reported reason. However, increased longevity is not always associated with improved cow welfare. The incidence of health problems is directly associated with a poor cow welfare status and older animals are more likely to develop health problems such as lameness [91] and mastitis [57] as well as body injuries [92]. Therefore, the increase in cow longevity should be the result of improving the ability of dairy farmers to keep animals healthy and comfortable, which in turn improves the overall animal welfare status.

The main reported reasons for involuntary culling imply a lower status of animal welfare, which was the primary issue raised by consumers towards an ideal dairy farm [93]. Leg problems such as lameness or foot disorders are considered the most detrimental condition on animal welfare $[89,94]$, while peripartum problems such as dystocia and retained placenta, which are associated with decreased reproductive performance, can be life-threatening or occur because of chronic stressful conditions [95].

Animal welfare becomes economically important to consumers once they attach importance to animal suffering [96]. Consumers from Europe [97] and the United States [98] indicated a willingness to pay more for animal-based products obtained from farms with high welfare status. European consumers also stated that products imported from other countries should be subject to the same level of welfare standards that are imposed on farmers in the European Union [97], which indicates that animal welfare could become a commercial barrier between countries [96,99]. Even though willingness to pay does not always translate into action, it would be prudent to expect that future demand for higher welfare status of dairy cattle among consumers will remain, including a demand for longer longevity [34].

\section{How Can We Improve Dairy Cow Longevity?}

Dairy cow longevity is the outcome of decisions made by dairy farmers throughout the life of the animal, which dictates the moment and the reason a cow is culled. It is a dynamic process where multiple factors and their interactions are to be considered by the farmer [3]. Therefore, all aspects of a cow's life need to be considered to reduce the rate of involuntary culling and increase longevity [1]. In addition, most lifetime metrics of longevity only become available once the animal is culled. To overcome such limitation, a currently rich area for research is the identification of metrics available earlier in the life of the animal that, in turn, are correlated with lifetime longevity metrics available later in life.

\subsection{Early Life Indicators}

\subsubsection{Age at First Calving and Its Association with Longevity Metrics}

Age at first calving (AFC) is a relatively early life metric, which has been extensively studied. The average AFC between high milk-producing countries is presented in Table 4, which ranged from 24.6 in the Netherland to 32.6 in Brazil. Age at first calving is associated with the ability of cows to remain in the herd and avoid culling, since animals that calved for the first time at a young age are less likely to be culled early during the productive life. Based on information from 437 herds across the United Kingdom, Sherwin et al. [100] reported that cows with an AFC greater than 30 months were 1.71 times more likely $(p<0.05)$ of being culled compared to animals with an AFC of 23-24 months. In another study conducted on 7768 Holstein heifers born between 2004 and 2006 in Spain, Bach [101] reported that heifers which finished their first lactation had an average AFC of 23.8 months compared with an average AFC of 24.2 months of animals that did not.

Age at first calving is also associated with the length of productive life. Swedish dairy cows that had an AFC of $27-28$ months were 1.1 times more likely $(p<0.05)$ to have a shorter length of productive life compared to animals with an AFC younger than 25 months [21]. Similar results were reported in a study carried out by Nilforooshan and 
Edriss [102] using production and pedigree data from Iranian Holstein cows collected between 1991 and 2011 from 45 herds, in which the length of productive life decreased as AFC increased $(p<0.05)$. The opposite was reported in a study using records from a single Australian farm from 1992 to 2005, in which animals with an AFC greater than 36 months had a longer length of life $(p<0.05)$ compared to animals calving for the first time between less than 24 to 36 months [28]. However, the opposite was observed for the longevity index in the same study $(p<0.05)$, indicating that animals with an older AFC had a longer length of life, possibly because the animals were inseminated older for the first time since the number of parities per lifetime did not differ $(p=0.28)$ between animals [28].

Table 4. Age at first calving (month) and length of life (year) of dairy cows in high milk-producing countries. The list of countries is limited to the world's top high milk-producing countries for which we were able to provide sufficient and reliable data on the length of productive life and recent age at first calving from official milk recording agencies.

\begin{tabular}{|c|c|c|c|c|c|c|c|c|c|}
\hline Country & Year & $\begin{array}{l}\text { Recorded } \\
\text { Herds }\end{array}$ & $\begin{array}{l}\text { Recorded } \\
\text { Cows }\end{array}$ & $\begin{array}{l}\text { Percentage } \\
\text { of } \\
\text { Recorded } \\
\text { Cows }{ }^{1}\end{array}$ & Breed & $\begin{array}{l}\text { Recorded } \\
\text { 1st Lac- } \\
\text { tations }\end{array}$ & $\begin{array}{l}\text { Age at } \\
\text { First } \\
\text { Calving }\end{array}$ & Reference & $\begin{array}{l}\text { Length } \\
\text { of Life }{ }^{2}\end{array}$ \\
\hline \multicolumn{10}{|l|}{ United } \\
\hline $\begin{array}{l}\text { State of } \\
\text { Amer- } \\
\text { ica }\end{array}$ & 2019 & 2140 & - & - & $\begin{array}{c}7 \text { different } \\
\text { dairy breeds }\end{array}$ & - & $25.5^{4}$ & AgSource [103] & 4.98 \\
\hline Brazil & 2018 & 334 & $15,459^{3}$ & 0.09 & $\begin{array}{l}\text { Girolando } \\
\text { (Holstein/Gir } \\
\text { crossbreed) }\end{array}$ & 12,384 & 32.6 & $\begin{array}{c}\text { GIROLANDO } \\
\text { [104] }\end{array}$ & 4.34 \\
\hline Germany & 2018 & - & - & - & $\begin{array}{l}15 \text { different } \\
\text { dairy breeds }\end{array}$ & 967,996 & 27.7 & BRS [105] & 5.67 \\
\hline France & 2018 & 35,253 & $2,437,250$ & 69.0 & $\begin{array}{l}20 \text { different } \\
\text { dairy breeds }\end{array}$ & 776,679 & $30.0^{5}$ & idele [106] & 4.59 \\
\hline Italy & 2019 & 15,316 & $1,351,442$ & 72.7 & $\begin{array}{l}30 \text { different } \\
\text { dairy breeds }\end{array}$ & 321,298 & $27.3^{5}$ & AIA [107] & 5.69 \\
\hline Poland & 2019 & 20,644 & 820,653 & 37.1 & $\begin{array}{l}12 \text { different } \\
\text { dairy breeds }\end{array}$ & 250,159 & 26.7 & PFHBIPM [108] & 6.23 \\
\hline Netherlanc & 18019 & 14,367 & $1,459,287$ & 91.9 & $\begin{array}{l}\text { Black-and- } \\
\text { white dairy } \\
\text { breeds, Red- } \\
\text { and-white } \\
\text { dairy breeds, } \\
\text { and others }\end{array}$ & - & 24.6 & CRV [12] & 5.88 \\
\hline Ireland & $\begin{array}{l}\text { April } \\
2020\end{array}$ & - & $1,599,498$ & - & - & - & 26.5 & $\begin{array}{c}\text { ICBF-Irish Cattle } \\
\text { Breeding } \\
\text { Federation [109] }\end{array}$ & $6.39^{7}$ \\
\hline Canada & 2019 & 7063 & 658,311 & 68.0 & - & - & $25.0^{6}$ & $\begin{array}{c}\text { CDIC [110], } \\
\text { Lactanet }[111,112]\end{array}$ & 3.89 \\
\hline
\end{tabular}

\footnotetext{
${ }^{1}$ Relative to the total number of cows in the country; ${ }^{2}$ Age at first calving plus the length of productive life from each country (Figure 5);

${ }^{3}$ Number of lactations recorded; ${ }^{4}$ Average of averages weighted over the number of herds by breed, since the number of recorded 1 st lactations was not available; ${ }^{5}$ Average of averages weighted over the number of recorded 1 st lactations; ${ }^{6}$ Median; ${ }^{7}$ Estimated using the length of productive life of 2018.
}

\subsubsection{Other Early Life Indicators and Their Association with Longevity Metrics}

Looking at longevity with AFC as the starting point overlooks early life (Figure 2) management practices and decisions made by the dairy farmer and their effect on the productive life of dairy cows. Even though it has received much less attention in the literature, there is an increasing interest in the subject. Housing calves from 3 to 7 months in litter pens with $\leq 12$ calves resulted in a median increase $(p<0.05)$ of 18.2 months in the survival time compared to calves housed in slatted pens with $>7$ calves [21]. The age in which the animal first consumed $0.91 \mathrm{~kg} / \mathrm{d}$ of grain (dry matter basis) was positively associated with the age when removed from the herd [113]. Additionally, housing automatically fed calves 
in small groups (6-9 calves) was associated with a higher growth rate $(0.022 \mathrm{~cm} /$ day, about $40 \mathrm{~g} /$ day, $p<0.05$ ) compared to calves housed in larger groups (12-18 calves; Svensson and Liberg [114]). In turn, the higher the average daily gain (ADG) of weight in different ages before the first calving, the younger $(p<0.05)$ the AFC [115]. In pasture-based dairy herds, Chuck et al. [116] reported a positive association $(p<0.05)$ between ADG from 1 month of age to first breeding on cumulative milk, fat, and protein yield at 100 and 250 days in milk in primiparous. Average daily gain from birth to weaning was also negatively associated $(p<0.05)$ with the occurrence of veterinary treated cases of mastitis from 7 to 30 days post-partum in primiparous cows [117].

Health events in early life, the season of birth, and inbreeding are associated with cow longevity. The occurrence of severe calfhood respiratory disease was associated with a $12 \%$ increase $(p<0.05)$ in the calving interval of Swedish Red dairy cows [118]. Fall- and winter-born calves had a higher 8-week calf starter intake (48.3 kg vs. $42.75 \mathrm{~kg}$ ), ADG (0.66 vs. $0.625 \mathrm{~kg} / \mathrm{d}$ ), and body weight (77.5 vs. $75.0 \mathrm{~kg}$ ) compared to spring- and summer-born calves $(p<0.05)$ [119]. While using Dairy Herd Improvement (DHI) data between 1980 and 2004 from Canadian Holstein cows ( $\mathrm{n}=1977311)$, Sewalem et al. [120] reported that animals with an inbreeding coefficient of 6.25 to $12.5 \%$ were 1.14 times more likely to have a shorter length of productive life, with the likelihood increasing as high as 1.51 times with inbreeding coefficient $\geq 25.0 \%$.

\subsubsection{Fetal Life and Its Association with Longevity Metrics}

Birth conditions are other less explored factors. The effect of complications during calving on dam longevity is well described in the literature. For instance, Holstein cows that require a hard pull and surgery during calving were 1.27 and 1.92 times more likely of being culled $(p<0.05)$, respectively compared to animals with unassisted calving [31]. However, the effect on offspring longevity has been less studied. A study conducted by Heinrichs and Heinrichs [113] on 21 dairy farms located in Pennsylvania, US reported that delivery scores indicating unassisted, easy pull, hard pull, mechanical extraction, or cesarean section were not associated $(p=0.11)$ with age when the offspring were removed from the herd. However, more studies are needed.

Fetal programming (the effect of dam conditions during conception and gestation on offspring performance) has been more extensively studied in beef [121,122] compared with dairy animals, but a few studies demonstrated associations between the dam's conditions on outcomes observed later in the life of the offspring. For instance, dam's intrauterine conditions associated with milk production seem to have an effect on offspring performance and survival [123], even though metabolic stress due to milk production might have a stronger effect than dam milk production alone [124]. In addition, high milk urea nitrogen is associated with decreased fertility in dairy cows $[125,126]$ and have a negative effect on early stages of oocyte development $[127,128]$. The longevity of calves originated from oocytes of cows with high milk urea nitrogen before ovulation has not been studied and accounting for the dam condition during pregnancy might be a possibility to improve offspring longevity [129].

\subsection{Lack of Space and Quota Constraints}

Dairy cow longevity is not only influenced by intrinsic cow factors, but also by extrinsic factors such as availability of space in the farm as well as market characteristics, which could also influence the involuntary culling. In a situation where there is a surplus of heifers, farmers would decide to cull animals to make space for heifers that just calved [13]. In places under a supply management system such as in Canada [4], it would be difficult to accommodate the increase in milk production as a result of having more cows in more productive lactations [5] as a result of increased longevity or when producers have contracts with dairy processors that limit the amount of milk they can deliver. Both conditions would influence decreasing the rate of involuntary culling and increasing longevity. 
A possible alternative would be to combine the use of sexed semen with extending the lactation of high-yielding cows by increasing the voluntary waiting period. Such a strategy would reduce the frequency that cows undergo the beginning of the lactation, which is associated with greater risk for involuntary culling due to death and diseases $[17,19,20]$. At the same time, the use of sexed semen would reduce the negative effect of extended lactation on the genetic return [130]. Extending the duration of lactation of high yielding animals was also shown to have no negative effect on the gain of body condition score, udder health, milk production, and culling [131] while improving their reproductive performance [132].

\title{
6. Proposing a More Comprehensive Definition of Cow Longevity
}

Contrarily to milk and milk components, dairy cow longevity is neither routinely measured nor reported. This could be partly justified by the lack of a sound definition of the term and, as a result, the nonexistence of a standard metric designed to cover all aspects outlined in the definition. The definition of longevity should take into account the health, reproductive performance, and milk production of any given animal during its entire lifespan, which in turn are key factors associated with culling [16-18] and the profitability of the dairy industry $[1,2,13,80]$. As much as possible, the definition should allow for the use of metrics that are already routinely collected from either farms or DHI agencies, making it easy to be implemented and to increase the chances of being widely adopted. To that end, dairy cow longevity could be defined as an animal having an early age at first calving and a long productive life spent under profitable levels of milk production.

This definition covers both early life conditions and the stayability of the animal once it reaches the lactating herd as well as its overall health and quality of life. Assuming that an animal would be inseminated for the first time as soon as it is ready, early age at first calving would indicate that the animal was raised under healthy and favorable early life conditions. Next, a long and profitable productive life would imply that the animal produced enough milk to justify keeping it under milking, reproduced regularly avoiding a potential extension of the lactation to unprofitable levels or unnecessarily long dry periods, and maintained good health since the incidence of health issues are directly linked with reproduction failures and reduction in milk production. Age at first calving, length of productive life, and margin over all costs are metrics that could be used as indicators of early life conditions, length of life, and profitability, respectively. Combined, they would provide a more comprehensive approach to measure dairy cow longevity (Figure 6).

\section{DAIRY COW LONGEVITY}

\section{PROFITABILITY}

\author{
Metric: Margin Over All Costs
}

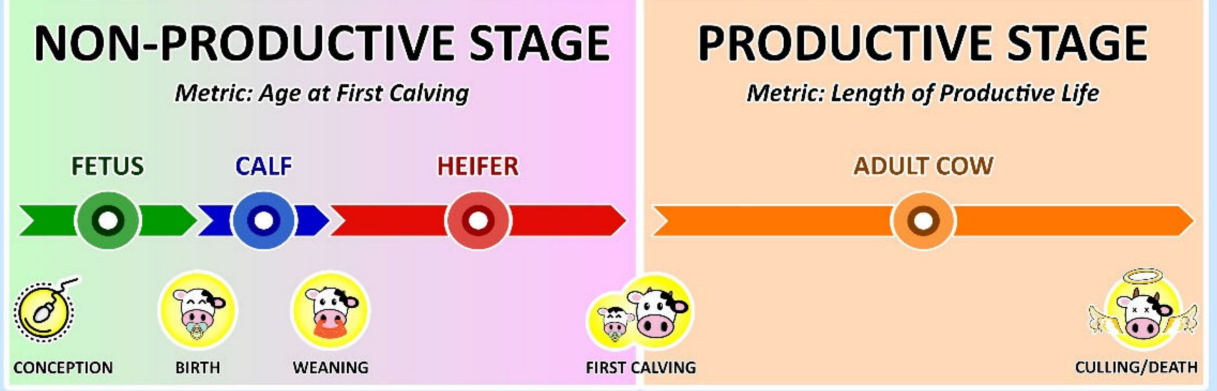

Figure 6. Relationship between the concepts of profitability, non-productive and productive life stages of dairy cows for a more comprehensive definition of cow longevity along with proposed metrics representing each respective concept. 


\section{Conclusions}

The current metrics available to measure longevity often starts at the first lactation, overlooking early life management practices and decisions made by the dairy farmer before that point. To overcome such limitation, first, we propose that dairy cow longevity should be defined as an animal having an early age at first calving and a long productive life spent under profitable levels of milk production. Next, a combination of the metrics age at first calving, length of productive life, and margin over all (available) costs would provide a more comprehensive evaluation of longevity and cover all aspects of the definition.

By using a standard methodology, this critical literature review confirms the concerns raised by the dairy industry and other stakeholders that dairy cow longevity has decreased in most high milk-producing countries. Early life indicators are needed to support farmers in the early selection of animals that are more likely to reach their maximum potential. Increasing cow longevity due to a reduction in involuntary culling would reduce health costs, increase cow lifetime profitability, improve animal welfare and quality of life, and contribute towards a more sustainable dairy industry by producing milk with inherited sustainability while optimizing dairy farmers' efficiency in the use of resources.

Author Contributions: Conceptualization, G.M.D. and E.V.; Methodology, G.M.D. and E.V.; Formal Analysis, G.M.D.; Investigation, G.M.D.; Resources, E.V.; Data Curation, G.M.D.; Writing-Original Draft Preparation, G.M.D. and E.V.; Writing-Review and Editing, G.M.D., K.M.W., R.I.C., J.T.M., R.L., D.P., and E.V.; Supervision, E.V.; Project Administration, E.V.; Funding Acquisition, E.V. and G.M.D. All authors have read and agreed to the published version of the manuscript.

Funding: This research was funded by the Novalait, Dairy Farmers of Canada, Valacta (now Lactanet), and Natural Sciences and Engineering Research Council (NSERC) as part of Industrial Research Chair in the Sustainable Life of Dairy Cattle (Chairholder: E.V., IRCPJ 492639-15). Stipend funding was provided to G.M.D. by the program CREATE in Milk Quality of NSERC, the Op+lait group of the Fonds de Recherche du Québec-Nature et Technologies (FRQNT), and McGill University, through the Pilarczyk Fellowship and Graduate Excellence Awards.

Institutional Review Board Statement: Not applicable.

Data Availability Statement: The data used in this study are available from the corresponding author, G.M.D.

Conflicts of Interest: The authors declare no conflict of interest. The sponsors had no role in the design, execution, interpretation, or writing of the study. 


\section{Appendix A}

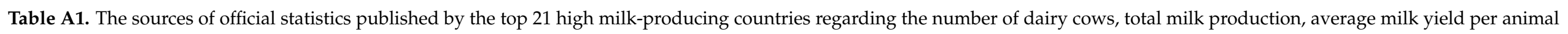
per year, and the number of slaughtered cows as well as data availability information.

\begin{tabular}{|c|c|c|c|c|c|}
\hline Country & Number of Dairy Cows & Total Milk Production & Milk Yield & Number of Slaughtered Cows & $\begin{array}{l}\text { Specify the Dairy } \\
\text { Category }\end{array}$ \\
\hline United States of America & FAO [35], USDA [133] & USDA [133] & USDA [133] and calculated & USDA [134] & Yes \\
\hline India & - & - & - & $\begin{array}{l}\text { Illegal to slaughter cows in most parts of the } \\
\text { country [135] }\end{array}$ & - \\
\hline Brazil & FAO [35], IBGE [136] & FAO [35], IBGE [137] & Calculated & IBGE [138] & No \\
\hline Germany & Destatis [139] & BZL [140], eurostat [141] & BZL [140] and calculated & Destatis [142] & No \\
\hline China, mainland & - & 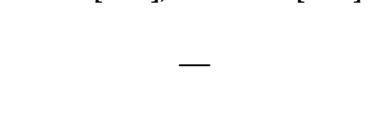 & 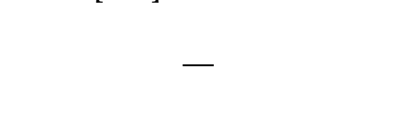 & $\begin{array}{l}\text { Reports the number of slaughtered cattle } \\
\text { and buffaloes combined and does not } \\
\text { specify cows }\end{array}$ & - \\
\hline Russian Federation & - & - & - & $\begin{array}{l}\text { Reports only the total live weight of } \\
\text { slaughtered cattle and does not specify cows }\end{array}$ & - \\
\hline France & eurostat [143] & eurostat $[141]$ & Calculated & eurostat [144] & No \\
\hline New Zealand & $\begin{array}{l}\text { FAO [35], NZ.Stat [145], } \\
\text { LIC \& DairyNZ [146] }\end{array}$ & $\begin{array}{l}\text { FAO [35], LIC \& DairyNZ } \\
\text { [146] }\end{array}$ & $\begin{array}{l}\text { LIC \& DairyNZ [146] and } \\
\text { calculated }\end{array}$ & NZ.Stat [147] & No \\
\hline Turkey & - & - & - & Only available for years 2015 to 2019 [144] & - \\
\hline Pakistan & - & - & - & Information not freely available & - \\
\hline United Kingdom & - & - & - & Not reliable over the years [144] & - \\
\hline Poland & FAO [35], eurostat [143] & FAO [35], eurostat [141] & Calculated & eurostat [144] & No \\
\hline Mexico & FAO [35] & FAO [35], SIACON [148] & Calculated & USDA [149] & No \\
\hline Italy & eurostat [143] & eurostat [141] & Calculated & eurostat [144] & No \\
\hline Argentina & FAO [35] & MAGyP [150] & Calculated & MAGyP [151] & No \\
\hline Ukraine & - & - & Calculated & Reports the number of slaughtered cattle & - \\
\hline Uzbekistan & - & - & Calculated & Reports not available & - \\
\hline Australia & - & - & - & $\begin{array}{c}\text { Reports the number of slaughtered cows } \\
\text { and heifers together }\end{array}$ & - \\
\hline Canada & Statistics Canada [152] & Statistics Canada [153] & Calculated & USDA [149] & No \\
\hline Ireland & FAO [35], eurostat [143] & eurostat [141] & Calculated & eurostat [144] & No \\
\hline
\end{tabular}




\section{References}

1. Essl, A. Longevity in dairy cattle breeding: A review. Livest. Prod. Sci. 1998, 57, 79-89. [CrossRef]

2. Fetrow, J.; Nordlund, K.V.; Norman, H.D. Invited Review: Culling: Nomenclature, definitions, and recommendations. J. Dairy Sci. 2006, 89, 1896-1905. [CrossRef]

3. Roche, S.M.; Renaud, D.L.; Genore, R.; Shock, D.A.; Bauman, C.; Croyle, S.; Barkema, H.W.; Dubuc, J.; Keefe, G.P.; Kelton, D.F. Canadian National Dairy Study: Describing Canadian dairy producer practices and perceptions surrounding cull cow management. J. Dairy Sci. 2020, 103, 3414-3421. [CrossRef]

4. Van Doormaal, B. A Closer Look at Longevity. Available online: https://www.cdn.ca/document.php?id=162 (accessed on 28 October 2020).

5. Brickell, J.S.; Wathes, D.C. A descriptive study of the survival of Holstein-Friesian heifers through to third calving on English dairy farms. J. Dairy Sci. 2011, 94, 1831-1838. [CrossRef]

6. Benbrook, C.; Carman, C.; Clark, E.A.; Daley, C.; Fulwider, W.; Hansen, M.; Leifert, C.; Martens, K.; Paine, L.; Petkewitz, L.; et al. A Dairy Farm's Footprint: Evaluating the Impacts of Conventional and Organic Farming Systems; The Organic Center: Washington, DC, USA, 2010; p. 35.

7. Grandl, F.; Furger, M.; Kreuzer, M.; Zehetmeier, M. Impact of longevity on greenhouse gas emissions and profitability of individual dairy cows analysed with different system boundaries. Animal 2019, 13, 198-208. [CrossRef]

8. Pellerin, D.; Adams, S.; Bécotte, F.; Cue, R.; Moore, R.; Roy, R. Pour une vache, l'âge d'or c'est la 4e lactation! In In Proceedings of the Symposium sur les Bovins Laitiers: Choix D'aujourd'hui Pour les Défis de Demain, CRAAQ—Le Centre de Référence en Agriculture et Agroalimentaire du Québec, Saint-Hyacinthe, QC, Canada, 5 November 2014; pp. 133-147.

9. Boulton, A.C.; Rushton, J.; Wathes, D.C. An empirical analysis of the cost of rearing dairy heifers from birth to first calving and the time taken to repay these costs. Animal 2017, 11, 1372-1380. [CrossRef] [PubMed]

10. De Vries, A. Economic trade-offs between genetic improvement and longevity in dairy cattle. J. Dairy Sci. 2017, 100, 4184-4192. [CrossRef] [PubMed]

11. DairyNZ. Animal Evaluation: Animal and Herd Averages. Available online: https://www.dairynz.co.nz/animal/animal-evalua tion/animal-and-herd-averages (accessed on 29 May 2020).

12. CRV. Jaarstatistieken 2019 Voor Nederland; CRV: Arnhem, The Netherlands, 2020; p. 55.

13. De Vries, A.; Marcondes, M.I. Review: Overview of factors affecting productive lifespan of dairy cows. Animal 2020, 14, s155-s164. [CrossRef] [PubMed]

14. Mark, T. Applied genetic evaluations for production and functional traits in dairy cattle. J. Dairy Sci. 2004, 87, 2641-2652. [CrossRef]

15. Weigel, K.A.; Palmer, R.W.; Caraviello, D.Z. Investigation of factors affecting voluntary and involuntary culling in expanding dairy herds in Wisconsin using survival analysis. J. Dairy Sci. 2003, 86, 1482-1486. [CrossRef]

16. CDIC. Culling and Replacement Rates in Dairy Herds in Canada. Available online: https://www.dairyinfo.gc.ca/eng/dairy-stat istics-and-market-information/dairy-animal-genetics / culling-and-replacement-rates-in-dairy-herds-in-canada/?id=1502475 693224 (accessed on 1 October 2020).

17. Heise, J.; Liu, Z.; Stock, K.F.; Rensing, S.; Reinhardt, F.; Simianer, H. The genetic structure of longevity in dairy cows. J. Dairy Sci. 2016, 99, 1253-1265. [CrossRef]

18. Compton, C.W.R.; Heuer, C.; Thomsen, P.T.; Carpenter, T.E.; Phyn, C.V.C.; McDougall, S. Invited review: A systematic literature review and meta-analysis of mortality and culling in dairy cattle. J. Dairy Sci. 2017, 100, 1-16. [CrossRef]

19. Pinedo, P.J.; De Vries, A.; Webb, D.W. Dynamics of culling risk with disposal codes reported by Dairy Herd Improvement dairy herds. J. Dairy Sci. 2010, 93, 2250-2261. [CrossRef]

20. Pinedo, P.J.; Daniels, A.; Shumaker, J.; De Vries, A. Dynamics of culling for Jersey, Holstein, and Jersey $\times$ Holstein crossbred cows in large multibreed dairy herds. J. Dairy Sci. 2014, 97, 2886-2895. [CrossRef]

21. Hultgren, J.; Svensson, C. Heifer rearing conditions affect length of productive life in Swedish dairy cows. Prev. Vet. Med. 2009, 89, 255-264. [CrossRef]

22. Haine, D.; Delgado, H.; Cue, R.; Sewalem, A.; Wade, K.; Lacroix, R.; Lefebvre, D.; Arsenault, J.; Bouchard, É.; Dubuc, J. Contextual herd factors associated with cow culling risk in Québec dairy herds: A multilevel analysis. Prev. Vet. Med. 2017, 144, 7-12. [CrossRef]

23. Stojkov, J.; von Keyserlingk, M.A.G.; Duffield, T.; Fraser, D. Management of cull dairy cows: Culling decisions, duration of transport, and effect on cow condition. J. Dairy Sci. 2020, 103, 2636-2649. [CrossRef]

24. Valacta. The Evolution of Valacta Atlantic Dairy Production: 2018 Stats \& Tips. 2019; Valacta: Sainte-Anne-de-Bellevue, QC, Canada, 2019 ; p. 41.

25. Villettaz Robichaud, M.; Rushen, J.; de Passillé, A.M.; Vasseur, E.; Haley, D.; Orsel, K.; Pellerin, D. Is the profitability of Canadian freestall farms associated with their performance on an animal welfare assessment? J. Dairy Sci. 2018, 101, 2350-2358. [CrossRef] [PubMed] 
26. Villettaz Robichaud, M.; Rushen, J.; de Passillé, A.M.; Vasseur, E.; Orsel, K.; Pellerin, D. Associations between on-farm animal welfare indicators and productivity and profitability on Canadian dairies: I. On freestall farms. J. Dairy Sci. 2019, 102, $4341-4351$. [CrossRef] [PubMed]

27. Villettaz Robichaud, M.; Rushen, J.; de Passillé, A.M.; Vasseur, E.; Haley, D.; Pellerin, D. Associations between on-farm cow welfare indicators and productivity and profitability on Canadian dairies: II. On tiestall farms. J. Dairy Sci. 2019, 102, 4352-4363. [CrossRef] [PubMed]

28. Haworth, G.M.; Tranter, W.P.; Chuck, J.N.; Cheng, Z.; Wathes, D.C. Relationships between age at first calving and first lactation milk yield, and lifetime productivity and longevity in dairy cows. Vet. Rec. 2008, 162, 643-647. [CrossRef]

29. Ducrocq, V. Statistical analysis of length of productive life for dairy cows of the Normande breed. J. Dairy Sci. 1994, 77, 855-866. [CrossRef]

30. Schneider, M.d.P.; Strandberg, E.; Emanuelson, U.; Grandinson, K.; Roth, A. The effect of veterinary-treated clinical mastitis and pregnancy status on culling in Swedish dairy cows. Prev. Vet. Med. 2007, 80, 179-192. [CrossRef] [PubMed]

31. Sewalem, A.; Miglior, F.; Kistemaker, G.J.; Sullivan, P.; Van Doormaal, B.J. Relationship between reproduction traits and functional longevity in Canadian dairy cattle. J. Dairy Sci. 2008, 91, 1660-1668. [CrossRef]

32. Van Pelt, M. Genetic Improvement of Longevity in Dairy Cows. Ph.D. Thesis, Wageningen University, Wageningen, The Netherlands, 24 March 2017. [CrossRef]

33. De Vries, A. Cow longevity economics: The cost benefit of keeping the cow in the herd. In Proceedings of the Cow Longevity Conference, Tumba, Sweeden, 28-29 August 2013; DeLaval: Tumba, Sweeden, 2013; pp. 22-52.

34. De Vries, A. Symposium review: Why revisit dairy cattle productive lifespan? J. Dairy Sci. 2020, 103, 3838-3845. [CrossRef]

35. Production: Livestock Primary. Available online: http://www.fao.org/faostat/en/\#data/QL (accessed on 2 April 2020).

36. Collier, R.J.; Dahl, G.E.; VanBaale, M.J. Major advances associated with environmental effects on dairy cattle. J. Dairy Sci. 2006, 89, 1244-1253. [CrossRef]

37. Shook, G.E. Major advances in determining appropriate selection goals. J. Dairy Sci. 2006, 89, 1349-1361. [CrossRef]

38. Polsky, L.; von Keyserlingk, M.A.G. Invited review: Effects of heat stress on dairy cattle welfare. J. Dairy Sci. 2017, 100, 8645-8657. [CrossRef]

39. Bryant, J.R.; López-Villalobos, N.; Pryce, J.E.; Holmes, C.W.; Johnson, D.L. Quantifying the effect of thermal environment on production traits in three breeds of dairy cattle in New Zealand. N. Z. J. Agric. Res. 2007, 50, 327-338. [CrossRef]

40. Rushen, J.; Passillé, A.M. The importance of improving cow longevity. In Proceedings of the Cow Longevity Conference, Tumba, Sweeden, 28-29 August 2013; DeLaval: Tumba, Sweeden, 2013; pp. 3-21.

41. Berry, D.P.; Harris, B.L.; Winkelman, A.M.; Montgomerie, W. Phenotypic associations between traits other than production and longevity in New Zealand dairy cattle. J. Dairy Sci. 2005, 88, 2962-2974. [CrossRef]

42. Pritchard, T.; Coffey, M.; Mrode, R.; Wall, E. Understanding the genetics of survival in dairy cows. J. Dairy Sci. 2013, 96, 3296-3309. [CrossRef]

43. McDougall, S.; Aberdein, D.; Bates, A.; Burke, C.R. Prevalence of endometritis diagnosed by vaginal discharge scoring or uterine cytology in dairy cows and herds. J. Dairy Sci. 2020. [CrossRef]

44. Ribeiro, E.S.; Lima, F.S.; Greco, L.F.; Bisinotto, R.S.; Monteiro, A.P.A.; Favoreto, M.; Ayres, H.; Marsola, R.S.; Martinez, N.; Thatcher, W.W.; et al. Prevalence of periparturient diseases and effects on fertility of seasonally calving grazing dairy cows supplemented with concentrates. J. Dairy Sci. 2013, 96, 5682-5697. [CrossRef]

45. Gilbert, R.O.; Shin, S.T.; Guard, C.L.; Erb, H.N.; Frajblat, M. Prevalence of endometritis and its effects on reproductive performance of dairy cows. Theriogenology 2005, 64, 1879-1888. [CrossRef]

46. Dubuc, J.; Duffield, T.F.; Leslie, K.E.; Walton, J.S.; LeBlanc, S.J. Effects of postpartum uterine diseases on milk production and culling in dairy cows. J. Dairy Sci. 2011, 94, 1339-1346. [CrossRef] [PubMed]

47. Giuliodori, M.J.; Magnasco, R.P.; Becu-Villalobos, D.; Lacau-Mengido, I.M.; Risco, C.A.; de la Sota, R.L. Metritis in dairy cows: Risk factors and reproductive performance. J. Dairy Sci. 2013, 96, 3621-3631. [CrossRef]

48. Olmos, G.; Mee, J.F.; Hanlon, A.; Patton, J.; Murphy, J.J.; Boyle, L. Peripartum health and welfare of Holstein-Friesian cows in a confinement-TMR system compared to a pasture-based system. Anim. Welf. 2009, 18, 467-476.

49. Washburn, S.P.; White, S.L.; Green, J.T.; Benson, G.A. Reproduction, mastitis, and body condition of seasonally calved Holstein and Jersey cows in confinement or pasture systems. J. Dairy Sci. 2002, 85, 105-111. [CrossRef]

50. Cavestany, D.; El-Wishy, A.B.; Foote, R.H. Effect of season and high environmental temperature on fertility of Holstein cattle. J. Dairy Sci. 1985, 68, 1471-1478. [CrossRef]

51. Rocha, A.; Randel, R.D.; Broussard, J.R.; Lim, J.M.; Blair, R.M.; Roussel, J.D.; Godke, R.A.; Hansel, W. High environmental temperature and humidity decrease oocyte quality in Bos taurus but not in Bos indicus cows. Theriogenology 1998, 49, 657-665. [CrossRef]

52. Olde Riekerink, R.G.M.; Barkema, H.W.; Kelton, D.F.; Scholl, D.T. Incidence rate of clinical mastitis on Canadian dairy farms. J. Dairy Sci. 2008, 91, 1366-1377. [CrossRef]

53. Van den Borne, B.H.P.; van Schaik, G.; Lam, T.J.G.M.; Nielen, M. Variation in herd level mastitis indicators between primi- and multiparae in Dutch dairy herds. Prev. Vet. Med. 2010, 96, 49-55. [CrossRef]

54. McDougall, S.; Arthur, D.; Bryan, M.; Vermunt, J.; Weir, A. Clinical and bacteriological response to treatment of clinical mastitis with one of three intramammary antibiotics. N. Z. Vet. J. 2007, 55, 161-170. [CrossRef] [PubMed] 
55. Busanello, M.; Rossi, R.S.; Cassoli, L.D.; Pantoja, J.C.F.; Machado, P.F. Estimation of prevalence and incidence of subclinical mastitis in a large population of Brazilian dairy herds. J. Dairy Sci. 2017, 100, 6545-6553. [CrossRef] [PubMed]

56. Bell, M.J.; Wilson, P. Estimated differences in economic and environmental performance of forage-based dairy herds across the UK. Food Energy Secur. 2018, 7, e00127. [CrossRef]

57. Firth, C.L.; Laubichler, C.; Schleicher, C.; Fuchs, K.; Käsbohrer, A.; Egger-Danner, C.; Köfer, J.; Obritzhauser, W. Relationship between the probability of veterinary-diagnosed bovine mastitis occurring and farm management risk factors on small dairy farms in Austria. J. Dairy Sci. 2019, 102, 4452-4463. [CrossRef] [PubMed]

58. Krömker, V.; Pfannenschmidt, F.; Helmke, K.; Andersson, R.; Grabowski, N.T. Risk factors for intramammary infections and subclinical mastitis in post-partum dairy heifers. J. Dairy Res. 2012, 79, 304-309. [CrossRef]

59. DeVries, T.J.; Aarnoudse, M.G.; Barkema, H.W.; Leslie, K.E.; von Keyserlingk, M.A.G. Associations of dairy cow behavior, barn hygiene, cow hygiene, and risk of elevated somatic cell count. J. Dairy Sci. 2012, 95, 5730-5739. [CrossRef]

60. Reneau, J.K.; Seykora, A.J.; Heins, B.J.; Endres, M.I.; Farnsworth, R.J.; Bey, F.R. Association between hygiene scores and somatic cell scores in dairy cattle. J. Am. Vet. Med. Assoc. 2005, 227, 1297-1301. [CrossRef] [PubMed]

61. Schreiner, D.A.; Ruegg, P.L. Relationship between udder and leg hygiene scores and subclinical mastitis. J. Dairy Sci. 2003, 86, 3460-3465. [CrossRef]

62. Nielsen, B.H.; Thomsen, P.T.; Sørensen, J.T. Identifying risk factors for poor hind limb cleanliness in Danish loose-housed dairy cows. Animal 2011, 5, 1613-1619. [CrossRef] [PubMed]

63. Sant'anna, A.C.; Paranhos da Costa, M.J. The relationship between dairy cow hygiene and somatic cell count in milk. J. Dairy Sci. 2011, 94, 3835-3844. [CrossRef] [PubMed]

64. Langford, F.M.; Stott, A.W. Culled early or culled late: Economic decisions and risks to welfare in dairy cows. Anim. Welf. 2012, 21, 41-55. [CrossRef]

65. Santman-Berends, I.M.G.A.; Swinkels, J.M.; Lam, T.J.G.M.; Keurentjes, J.; van Schaik, G. Evaluation of udder health parameters and risk factors for clinical mastitis in Dutch dairy herds in the context of a restricted antimicrobial usage policy. J. Dairy Sci. 2016, 99, 2930-2939. [CrossRef]

66. Fabian, J.; Laven, R.A.; Whay, H.R. The prevalence of lameness on New Zealand dairy farms: A comparison of farmer estimate and locomotion scoring. Vet. J. 2014, 201, 31-38. [CrossRef] [PubMed]

67. Higginson Cutler, J.H.; Rushen, J.; de Passillé, A.M.; Gibbons, J.; Orsel, K.; Pajor, E.; Barkema, H.W.; Solano, L.; Pellerin, D.; Haley, D.; et al. Producer estimates of prevalence and perceived importance of lameness in dairy herds with tiestalls, freestalls, and automated milking systems. J. Dairy Sci. 2017, 100, 9871-9880. [CrossRef]

68. Espejo, L.A.; Endres, M.I.; Salfer, J.A. Prevalence of lameness in high-producing Holstein cows housed in freestall barns in Minnesota. J. Dairy Sci. 2006, 89, 3052-3058. [CrossRef]

69. Haskell, M.J.; Rennie, L.J.; Bowell, V.A.; Bell, M.J.; Lawrence, A.B. Housing system, milk production, and zero-grazing effects on lameness and leg injury in dairy cows. J. Dairy Sci. 2006, 89, 4259-4266. [CrossRef]

70. Adams, A.E.; Lombard, J.E.; Fossler, C.P.; Román-Muñiz, I.N.; Kopral, C.A. Associations between housing and management practices and the prevalence of lameness, hock lesions, and thin cows on US dairy operations. J. Dairy Sci. 2017, 100, 2119-2136. [CrossRef]

71. Somers, J.G.C.J.; Frankena, K.; Noordhuizen-Stassen, E.N.; Metz, J.H.M. Prevalence of claw disorders in Dutch dairy cows exposed to several floor systems. J. Dairy Sci. 2003, 86, 2082-2093. [CrossRef]

72. Vanegas, J.; Overton, M.; Berry, S.L.; Sischo, W.M. Effect of rubber flooring on claw health in lactating dairy cows housed in free-stall barns. J. Dairy Sci. 2006, 89, 4251-4258. [CrossRef]

73. Hernandez-Mendo, O.; von Keyserlingk, M.A.G.; Veira, D.M.; Weary, D.M. Effects of pasture on lameness in dairy cows. J. Dairy Sci. 2007, 90, 1209-1214. [CrossRef]

74. Olmos, G.; Boyle, L.; Hanlon, A.; Patton, J.; Murphy, J.J.; Mee, J.F. Hoof disorders, locomotion ability and lying times of cubicle-housed compared to pasture-based dairy cows. Livestock Sci. 2009, 125, 199-207. [CrossRef]

75. Beggs, D.S.; Jongman, E.C.; Hemsworth, P.H.; Fisher, A.D. Lame cows on Australian dairy farms: A comparison of farmeridentified lameness and formal lameness scoring, and the position of lame cows within the milking order. J. Dairy Sci. 2019, 102, 1522-1529. [CrossRef]

76. Huxley, J.N. Impact of lameness and claw lesions in cows on health and production. Livestock Sci. 2013, 156, 64-70. [CrossRef]

77. Thompson, A.J.; Weary, D.M.; Bran, J.A.; Daros, R.R.; Hötzel, M.J.; von Keyserlingk, M.A.G. Lameness and lying behavior in grazing dairy cows. J. Dairy Sci. 2019, 102, 6373-6382. [CrossRef] [PubMed]

78. Ranjbar, S.; Rabiee, A.R.; Gunn, A.; House, J.K. Identifying risk factors associated with lameness in pasture-based dairy herds. J. Dairy Sci. 2016, 99, 7495-7505. [CrossRef] [PubMed]

79. Moreira, T.F.; Nicolino, R.R.; Meneses, R.M.; Fonseca, G.V.; Rodrigues, L.M.; Facury Filho, E.J.; Carvalho, A.U. Risk factors associated with lameness and hoof lesions in pasture-based dairy cattle systems in southeast Brazil. J. Dairy Sci. 2019, 102, 10369-10378. [CrossRef] [PubMed]

80. Mulder, H.; Jansen, G. Derivation of economic values using lifetime profitability of Canadian Holstein cows. Parity 2001, 1, 1-10.

81. Komlósi, I.; Wolfová, M.; Wolf, J.; Farkas, B.; Szendrei, Z.; Béri, B. Economic weights of production and functional traits for Holstein-Friesian cattle in Hungary. J. Anim. Breed. Genet. 2010, 127, 143-153. [CrossRef] 
82. Dhuyvetter, K.; Kastens, T.; Overton, M.; Smith, J. Cow culling decisions: Costs or economic opportunity? In Proceedings of the Western Dairy Management Conference, Reno, NV, USA, 7-9 March 2007; pp. 173-187.

83. Britt, J.H.; Cushman, R.A.; Dechow, C.D.; Dobson, H.; Humblot, P.; Hutjens, M.F.; Jones, G.A.; Ruegg, P.S.; Sheldon, I.M.; Stevenson, J.S. Invited review: Learning from the future-A vision for dairy farms and cows in 2067. J. Dairy Sci. 2018, 101, 3722-3741. [CrossRef]

84. Walter, A.; Finger, R.; Huber, R.; Buchmann, N. Opinion: Smart farming is key to developing sustainable agriculture. Proc. Natl. Acad. Sci. USA 2017, 114, 6148. [CrossRef]

85. Wall, E.; Coffey, M.P.; Pollott, G.E. The effect of lactation length on greenhouse gas emissions from the national dairy herd. Animal 2012, 6, 1857-1867. [CrossRef]

86. Knapp, J.R.; Laur, G.L.; Vadas, P.A.; Weiss, W.P.; Tricarico, J.M. Invited review: Enteric methane in dairy cattle production: Quantifying the opportunities and impact of reducing emissions. J. Dairy Sci. 2014, 97, 3231-3261. [CrossRef]

87. Grandl, F.; Amelchanka, S.L.; Furger, M.; Clauss, M.; Zeitz, J.O.; Kreuzer, M.; Schwarm, A. Biological implications of longevity in dairy cows: 2. Changes in methane emissions and efficiency with age. J. Dairy Sci. 2016, 99, 3472-3485. [CrossRef]

88. Berry, D.P. Breeding the dairy cow of the future: What do we need? Anim. Prod. Sci. 2015, 55, 823-837. [CrossRef]

89. Bruijnis, M.R.N.; Meijboom, F.L.B.; Stassen, E.N. Longevity as an animal welfare issue applied to the case of foot disorders in dairy cattle. J. Agric. Environ. Ethics 2013, 26, 191-205. [CrossRef]

90. Kumar, N.; Manimaran, A.; Kumaresan, A.; Jeyakumar, S.; Sreela, L.; Mooventhan, P.; Sivaram, M. Mastitis effects on reproductive performance in dairy cattle: A review. Trop. Anim. Health Prod. 2017, 49, 663-673. [CrossRef] [PubMed]

91. Pötzsch, C.J.; Collis, V.J.; Blowey, R.W.; Packington, A.J.; Green, L.E. The Impact of Parity and Duration of Biotin Supplementation on White Line Disease Lameness in Dairy Cattle. J. Dairy Sci. 2003, 86, 2577-2582. [CrossRef]

92. Bouffard, V.; de Passillé, A.M.; Rushen, J.; Vasseur, E.; Nash, C.G.R.; Haley, D.B.; Pellerin, D. Effect of following recommendations for tiestall configuration on neck and leg lesions, lameness, cleanliness, and lying time in dairy cows. J. Dairy Sci. 2017, 100, 2935-2943. [CrossRef] [PubMed]

93. Cardoso, C.S.; Hötzel, M.J.; Weary, D.M.; Robbins, J.A.; von Keyserlingk, M.A.G. Imagining the ideal dairy farm. J. Dairy Sci. 2016, 99, 1663-1671. [CrossRef]

94. von Keyserlingk, M.A.G.; Rushen, J.; de Passillé, A.M.; Weary, D.M. Invited review: The welfare of dairy cattle-Key concepts and the role of science. J. Dairy Sci. 2009, 92, 4101-4111. [CrossRef] [PubMed]

95. Burnett, T.A.; Madureira, A.M.L.; Silper, B.F.; Tahmasbi, A.; Nadalin, A.; Veira, D.M.; Cerri, R.L.A. Relationship of concentrations of cortisol in hair with health, biomarkers in blood, and reproductive status in dairy cows. J. Dairy Sci. 2015, 98, 4414-4426. [CrossRef] [PubMed]

96. Molento, C.F.M. Bem-estar e produção animal: Aspectos econômicos. Arch. Vet. Sci. 2005, 10, 1-11. [CrossRef]

97. European Commission. Attitudes of Europeans Towards Animal Welfare; European Commission: Brussels, Belgium, 2016 ; p. 86. [CrossRef]

98. Wolf, C.A.; Tonsor, G.T. Cow welfare in the U.S. dairy industry: Willingness-to-pay and willingness-to-supply. J. Agric. Resour. Econ. 2017, 42, 164-179. [CrossRef]

99. Bond, G.B.; Almeida, R.d.; Ostrensky, A.; Molento, C.F.M. Métodos de diagnóstico e pontos críticos de bem-estar de bovinos leiteiros. Ciência Rural 2012, 42, 1286-1293. [CrossRef]

100. Sherwin, V.E.; Hudson, C.D.; Henderson, A.; Green, M.J. The association between age at first calving and survival of first lactation heifers within dairy herds. Animal 2016, 10, 1877-1882. [CrossRef]

101. Bach, A. Associations between several aspects of heifer development and dairy cow survivability to second lactation. J. Dairy Sci. 2011, 94, 1052-1057. [CrossRef]

102. Nilforooshan, M.A.; Edriss, M.A. Effect of age at first calving on some productive and longevity traits in Iranian Holsteins of the Isfahan province. J. Dairy Sci. 2004, 87, 2130-2135. [CrossRef]

103. AgSource. Industry Benchmarks: AgSource Breed. Averages; AgSource: Madison, Wisconsin, USA, 2020.

104. GIROLANDO-Associação Brasileira dos Criadores de Girolando; (Uberaba, Minas Gerais, Brazil). Personal communication, 2020.

105. BRS-Bundesverband Rind und Schwein e.V. Rinder-Und Schweineproduktion in Deutschland; BRS: Bonn, Germany, 2019.

106. Idele. Resultats de Controle Laitier des Especes Bovine, Caprine et Ovine: France 2018; Thomas, G., Astruc, J.M., Bourrigan, X., Eds.; Institut de l'Elevage \& France Conseil Elevage: Paris, France, 2019; p. 167.

107. AIA. Bollettino dei Controlli Della Produttività del Latte, 58th ed.; AIA: Roma, Italy, 2020.

108. PFHBIPM. Mlecznego Ocena i Hodowla Bydła Mlecznego: Dane za Rok 2019; PFHBIPM: Warsaw, Poland, 2020.

109. ICBF-Irish Cattle Breeding Federation; (Bandon, County Cork, Ireland). Personal Communication, 2020.

110. CDIC. Number of Farms, Dairy Cows and Dairy Heifers. Available online: https:/ / dairyinfo.gc.ca/eng/dairy-statistics-and-m arket-information / farm-statistics / farms-dairy-cows-and-dairy-heifers / ?id=1502467423238\&menupos=01.01.14 (accessed on 20 April 2020).

111. Lactanet. Herd Benchmarks: Management Centre. Available online: http://canwestdhi.com/pdf_files/2019\%20benchmarks/201 9\%20Management\%20Centre\%20Canada\%20Lactanet\%20Herds\%20(English).pdf (accessed on 18 April 2020).

112. Lactanet. 2019 Annual Report E 2020 Business Plan; Lactanet: Guelph, ON, Canada; Sainte-Anne-de-Bellevue, QC, Canada, 2020; p. 25. 
113. Heinrichs, A.J.; Heinrichs, B.S. A prospective study of calf factors affecting first-lactation and lifetime milk production and age of cows when removed from the herd. J. Dairy Sci. 2011, 94, 336-341. [CrossRef]

114. Svensson, C.; Liberg, P. The effect of group size on health and growth rate of Swedish dairy calves housed in pens with automatic milk-feeders. Prev. Vet. Med. 2006, 73, 43-53. [CrossRef]

115. Vacek, M.; Krpálková, L.; Syrůček, J.; Štípková, M.; Janecká, M. Relationships between growth and body condition development during the rearing period and performance in the first three lactations in Holstein cows. Czech. J. Anim. Sci. 2015, 60, 417-425. [CrossRef]

116. Chuck, G.M.; Mansell, P.D.; Stevenson, M.A.; Izzo, M.M. Early-life events associated with first-lactation performance in pasturebased dairy herds. J. Dairy Sci. 2018, 101, 3488-3500. [CrossRef] [PubMed]

117. Svensson, C.; Nyman, A.K.; Waller, K.P.; Emanuelson, U. Effects of housing, management, and health of dairy heifers on first-lactation udder health in southwest Sweden. J. Dairy Sci. 2006, 89, 1990-1999. [CrossRef]

118. Hultgren, J.; Svensson, C. Calving interval in dairy cows in relation to heifer rearing conditions in southwest Sweden. Reprod. Domest. Anim. 2010, 45, 136-141. [CrossRef] [PubMed]

119. Chester-Jones, H.; Heins, B.J.; Ziegler, D.; Schimek, D.; Schuling, S.; Ziegler, B.; de Ondarza, M.B.; Sniffen, C.J.; Broadwater, N. Relationships between early-life growth, intake, and birth season with first-lactation performance of Holstein dairy cows. J. Dairy Sci. 2017, 100, 3697-3704. [CrossRef] [PubMed]

120. Sewalem, A.; Kistemaker, G.J.; Miglior, F.; Van Doormaal, B.J. Analysis of inbreeding and its relationship with functional longevity in Canadian dairy cattle. J. Dairy Sci. 2006, 89, 2210-2216. [CrossRef]

121. Du, M.; Tong, J.; Zhao, J.; Underwood, K.R.; Zhu, M.; Ford, S.P.; Nathanielsz, P.W. Fetal programming of skeletal muscle development in ruminant animals. J. Anim. Sci. 2010, 88, E51-E60. [CrossRef]

122. Du, M.; Ford, S.P.; Zhu, M.-J. Optimizing livestock production efficiency through maternal nutritional management and fetal developmental programming. Anim. Front. 2017, 7, 5-11. [CrossRef]

123. Berry, D.P.; Lonergan, P.; Butler, S.T.; Cromie, A.R.; Fair, T.; Mossa, F.; Evans, A.C.O. Negative influence of high maternal milk production before and after conception on offspring survival and milk production in dairy cattle. J. Dairy Sci. 2008, 91, 329-337. [CrossRef]

124. Bach, A. Ruminant Nutrition Symposium: Optimizing performance of the offspring: Nourishing and managing the dam and postnatal calf for optimal lactation, reproduction, and immunity. J. Anim. Sci. 2012, 90, 1835-1845. [CrossRef]

125. Rajala-Schultz, P.J.; Saville, W.J.A.; Frazer, G.S.; Wittum, T.E. Association between milk urea nitrogen and fertility in Ohio dairy cows. J. Dairy Sci. 2001, 84, 482-489. [CrossRef]

126. Butler, W.R.; Calaman, J.J.; Beam, S.W. Plasma and milk urea nitrogen in relation to pregnancy rate in lactating dairy cattle. J. Anim. Sci. 1996, 74, 858-865. [CrossRef] [PubMed]

127. Kowsar, R.; Izadi, F.; Sadeghi, N.; Riasi, A.; Zadegan, F.G.; Hajian, M.; Nasr-Esfahani, M.H.; Farrokhpour, H.; Miyamoto, A. Urea changes oocyte competence and gene expression in resultant bovine embryo in vitro. Zygote 2018, 26, 207-219. [CrossRef] [PubMed]

128. De Wit, A.A.C.; Cesar, M.L.F.; Kruip, T.A.M. Effect of urea during in vitro maturation on nuclear maturation and embryo development of bovine cumulus-oocyte-complexes. J. Dairy Sci. 2001, 84, 1800-1804. [CrossRef]

129. Opsomer, G.; Van Eetvelde, M.; Kamal, M.; Van Soom, A. Epidemiological evidence for metabolic programming in dairy cattle. Reprod. Fertil. Dev. 2017, 29, 52-57. [CrossRef] [PubMed]

130. Clasen, J.B.; Lehmann, J.O.; Thomasen, J.R.; Østergaard, S.; Kargo, M. Combining extended lactation with sexed semen in a dairy cattle herd: Effect on genetic and total economic return. Livestock Sci. 2019, 223, 176-183. [CrossRef]

131. Niozas, G.; Tsousis, G.; Malesios, C.; Steinhöfel, I.; Boscos, C.; Bollwein, H.; Kaske, M. Extended lactation in high-yielding dairy cows. II. Effects on milk production, udder health, and body measurements. J. Dairy Sci. 2019, 102, 811-823. [CrossRef]

132. Niozas, G.; Tsousis, G.; Steinhöfel, I.; Brozos, C.; Römer, A.; Wiedemann, S.; Bollwein, H.; Kaske, M. Extended lactation in high-yielding dairy cows. I. Effects on reproductive measurements. J. Dairy Sci. 2019, 102, 799-810. [CrossRef]

133. Annual Milk Production and Factors Affecting Supply (Annual). Available online: https://www.ers.usda.gov/data-products/d airy-data/ (accessed on 2 April 2020).

134. Livestock and Poultry Slaughter (Historical). Available online: https:/ /www.ers.usda.gov/data-products/livestock-meat-dome stic-data/livestock-meat-domestic-data/\#Livestock\%20and\%20poultry\%20slaughter (accessed on 2 April 2020).

135. Narayanan, Y. Jugaad and informality as drivers of India's cow slaughter economy. Environ. Plan. A Econ. Space 2019, 51, 1516-1535. [CrossRef]

136. Pesquisa da Pecuária Municipal-Table 94. Available online: https://sidra.ibge.gov.br/tabela/94 (accessed on 2 April 2020).

137. Pesquisa da Pecuária Municipal-Table 74. Available online: https://sidra.ibge.gov.br/tabela/74 (accessed on 2 April 2020).

138. Pesquisa Trimestral do Abate de Animais-Table 1092. Available online: https://sidra.ibge.gov.br/tabela/1092 (accessed on 2 April 2020).

139. Gehaltene Tiere: Deutschland, Jahre, Tierarten. Available online: https://www-genesis.destatis.de/genesis / / online?operation= table\&code $=41311-0001 \& l e v e l i n d e x=0 \& l e v e l i d=1585877656772$ (accessed on 2 April 2020).

140. Milcherzeugung und -Verwendung 2019. Available online: https://www.ble.de/DE/BZL/Daten-Berichte/Milch-Milcherzeugni sse/_functions/TabelleMilcherzeugungVerwendung2019.html?nn=8906974 (accessed on 2 April 2020). 
141. Production and Utilization of Milk on the Farm (Annual Data). Available online: https://appsso.eurostat.ec.europa.eu/nui/sho w.do?dataset=apro_mk_farm\&lang=en (accessed on 2 April 2020).

142. Geschlachtete Tiere, Schlachtmenge: Deutschland, Jahre, Tierarten, Schlachtungsart. Available online: https://www-genesis.dest atis.de / genesis / / online?operation=table\&code=41331-0001\&levelindex=0\&levelid=1585878027052 (accessed on 2 April 2020).

143. Bovine Population (Annual Data). Available online: https://appsso.eurostat.ec.europa.eu/nui/show.do?dataset=apro_mt_lscat 1\&lang=en (accessed on 13 April 2020).

144. Slaughtering in Slaughterhouses (Annual Data). Available online: https://appsso.eurostat.ec.europa.eu/nui/show.do?dataset=a pro_mt_pann\&lang=en (accessed on 8 April 2020).

145. Variable by Total New Zealand (Annual-Jun). Available online: http://archive.stats.govt.nz/infoshare/ (accessed on 13 April 2020).

146. LIC \& DairyNZ. New Zealand Dairy Statistics 2018-2019 Report; LIC—Livestock Improvement Corporation \& DairyNZ: Hamilton, New Zealand, 2019.

147. Total New Zealand by Kill by Animal Type (Annual-Dec). Available online: http://archive.stats.govt.nz/infoshare/ (accessed on 8 April 2020).

148. SIACON. Pecuario Estatal; Secretaría de Agricultura y Desarrollo Rural (SADER) \& Servicio de Información Agroalimentaria y Pesquera (SIAP): Mexico City, Mexico, 2020.

149. Production, Supply and Distribution (PSD) 2014 Table Livestock and Poultry. Available online: https://apps.fas.usda.gov/psdo nline/downloads/psd_livestock_csv.zip (accessed on 8 April 2020).

150. Producción Primaria. Available online: https://www.magyp.gob.ar/sitio/areas/ss_lecheria/estadisticas/_01_primaria/index.p hp (accessed on 14 April 2020).

151. Ganadería-Indicadores Bovinos Anuales. Available online: https://datos.agroindustria.gob.ar/dataset/indicadores-anuales-s ector-bovino (accessed on 14 April 2020).

152. Number of Cattle, by Class and Farm Type (x 1000). Available online: https://doi.org/10.25318/3210013001-eng (accessed on 13 April 2020).

153. Milk Production and Utilization. Available online: https://doi.org/10.25318/3210011301-eng (accessed on 13 April 2020). 